Structures of Epic Poetry 


\section{Structures of Epic Poetry Volume III: Continuity}

Edited by

Christiane Reitz and Simone Finkmann

\section{DE GRUYTER}


ISBN 978-3-11-049200-2

e-ISBN (PDF) 978-3-11-049259-0

e-ISBN (EPUB) 978-3-11-049167-8

Library of Congress Control Number: 2019953831

Bibliographic information published by the Deutsche Nationalbibliothek

The Deutsche Nationalbibliothek lists this publication in the Deutsche Nationalbibliografie; detailed bibliographic data are available on the Internet at http://dnb.dnb.de.

(C) 2019 Walter de Gruyter GmbH, Berlin/Boston Typesetting: Eric Naujoks (Rostock), Dr. Jörn Kobes (Gutenberg) Cover image: Carrara Marble Quarries, (c) Wulf Liebau ( $\dagger$ ), Photograph: Courtesy of Irene Liebau Printing and binding: CPI books $\mathrm{GmbH}$, Leck

www.degruyter.com 


\section{Contents}

Christiane Reitz and Simone Finkmann

The origin, tradition, and reinvention of epic structures - a short

introduction -1

Johannes Haubold

Poetic form and narrative theme in early Greek and Akkadian epic - 7

Simon Zuenelli

The transformation of the epic genre in Late Antiquity - 25

Berenice Verhelst

Greek biblical epic: Nonnus' Paraphrase and Eudocia's Homerocentones - 53

Christoph Schubert

Between imitation and transformation: the (un)conventional use of epic

structures in the Latin biblical poetry of Late Antiquity - 79

Martin Bažil

Epic forms and structures in late antique Vergilian centos - 135

Kristoffel Demoen and Berenice Verhelst

The tradition of epic poetry in Byzantine literature - 175

Wim Verbaal

Medieval epicity and the deconstruction of classical epic -211

Christian Peters

Narrative structures in Neo-Latin epic from 1440 to $1500-257$

Florian Schaffenrath

Narrative structures in Neo-Latin epic: $16^{\text {th }}-19^{\text {th }}$ century -301

Matteo Romanello

Experiments in digital publishing: creating a digital compendium - 331 
VI Contents

Overview: Graeco-Roman epyllia and epics from Homer to Late Antiquity -349

Core bibliography - 357

Indices - 389

List of contributors -417 


\title{
Medieval epicity and the deconstruction of classical epic
}

\begin{abstract}
In the literary history of epic poetry medieval Latin epics do not very often appear. Poems that conform to epical standards seem rare or even absent. Simultaneously, however, vernacular epic flourishes and is recognised as such. For that reason, one might wonder if the apparent absence of medieval Latin epic is not rather due to the scholars' eyes that perhaps are too much preconditioned by a classicist understanding of 'epicity'. This contribution wants to open up the discussion by presenting medieval Latin epicity as a very specific and conscious way of dealing with the classical models, more based upon deconstruction and recreation than on the imitation of normative models.
\end{abstract}

\section{Preliminary remarks: medieval Latin epics?}

In a multivolume standard work on the structural elements of classical epic and their reception and transformation it seems bizarre or even ridiculous to ask for the existence of epic poems during the long period that separated antiquity from its so-called revival in the Renaissance. Yet, the question has to be asked, or rather, it has been asked, and the answers vary greatly according to the background of the scholar concerned. The answer is emphatically affirmative for the great group of scholars focussing on the vernacular. Indeed, who would question that the Beowulf, the Chanson de Roland, or the Nibelungenlied should be classified as epics, to name only the most famous representatives? Not even the most rigidly classicist scholars will deny the epic character of these and other works, even though their links to what they perceive to be the norm, classical epic, are all but evident and clear. ${ }^{1}$ However, their profile as 'primary' epics suffices to place them on a comparable level with the Homeric epics, the 'primacy' of which is considered indisputable.

Moreover, their 'primacy' is not only due to their being the first in time as regards the literature in their specific vernacular tongue. Still of greater importance is the political impact they are supposed to have had. They are viewed as essential founding texts for the linguistic and literary identity of the nations that later would

1 Cf. Hainsworth (1991, 137): "But generally the vernacular epic of the Middle Ages was quite innocent of these classical pretensions.”

https://doi.org/10.1515/9783110492590-071 
constitute themselves around their vernacular tongues, even when this primacy in chronological and political sense was only constructed afterwards. For this reason, a large amount of scholarship exists on these texts, which, besides the philological aspects of manuscript transmission and edition, seems to have three focal points: 1) the already mentioned primacy of the epic and its political significance; 2) the cyclisation of originally independent epics into genealogical lines around a central hero; 3) the dialogue between the different vernacular literary traditions. ${ }^{2}$

Questions about the epic character of these and similar texts are asked and normally answered by opposing them to another genre. In Medieval Studies this genre is often given as le roman, which is distinguished from the epic genre in its focus on the individual hero instead of a political community. ${ }^{3}$ The quest of the knight in the chivalric romance is always a personal quest, meant to prove his individual values, whereas in medieval epic the hero always submits his personal objectives to those of the nation or the group to which he belongs and of which he is the representative par excellence. ${ }^{4}$

Until today a huge blind spot remains in scholarship on medieval epic. Latin poetry is almost entirely absent from all studies concerning the epic genre during the Middle Ages. And those few scholars who gave it their attention seem convinced that Latin epics either are extremely rare or even do not exist at all. Tyssens (1988, 39-41) does not recognise more than a dozen poems. All the others are considered products of the schools, artificial or even little more than centos. Therefore, poems treating hagiographic, historical, or historical-legendary topics are eliminated, even when many of them possess "les couleurs de l'épopée”.

Less rigid is Schaller in his different contributions on the problem. ${ }^{5}$ As one of the few scholars who tried to delineate the characteristics of medieval Latin epic, his approach still became nearly as exclusive as Tyssens'. Ward (1993, 261-93), on the contrary, tried to avoid a categorical approach and opted instead for a broader definition, rather wanting to illustrate his view by way of one example (the anonymous Waltharius, c. $10^{\text {th }}$ century), ${ }^{6}$ without commenting explicitly on the epic character of a text. Strangely enough, this is constantly done by the editors of medieval poems that could without problems claim the epic statute. In the Italian

2 It is simply impossible to provide even a minimal bibliographical list on vernacular epics that were composed during the Middle Ages. A seminal work of reference remains Boyer et al. (1988).

3 Cf. Paquette (1988, 19-20).

4 Similarly, unlike the knight of the romance novel, the epic hero very rarely has to deal with inner conflicts.

5 Cf. Schaller (1989) and Schaller (1993).

6 Cf. Strecker (1951). 
re-edition of Hrotsvitha's hagiographical and historical poems ${ }^{7}$ the editors refuse to call her Gesta Ottonis, the poem on Otto the Great, an epic, as it misses the 'essential elements' that make it an epic. ${ }^{8}$ An entirely opposite approach is taken by those in charge of the entry "Epos" in the Lexikon des Mittelalters: they seem to include almost every narrative poem in the category of 'epic'. ${ }^{9}$

From all this uncertainty one can only conclude that the question has been asked incorrectly. We should not decide if a poem is epic or not, but rather how the epic character of a text can be recognised. In other words, what makes up its 'epicity'? ${ }^{10}$ For the Latin poetry of the Middle Ages, only Schaller (1993, 9-42) has tried to distinguish the characteristics a poem must possess if it wants to be classified as an 'epic'. First of all, according to him, an epic poem ought to display a structured unity in its narrative plot, which apparently excludes a purely chronological development. Simultaneously, the poem must have a propensity for textual extension (Schaller calls this characteristic "episches Behagen") and delay, which seems to suggest that chances for digressions are exploited to the fullest. There must also be a surprising variation in descriptions, events, speeches, thus avoiding a too strong focus on one predominant topic. Figures of speech and of thought as well as stylistic features (similitudines, comparisons, catalogues, digressions, lyrical interludes) are present and applied in a strategic way. Finally, it must have originally been intended for performance, despite having been composed as a written poem.

It may be clear from the outset that this approach to epic poetry is first of all prescriptive and based on a strongly classicist normativity. Each of these qualities seems to have been derived from the Homeric and Vergilian model, although their application would imply that several of the ancient epics themselves would no longer conform to the concept of 'epicity'. How should we call Ennius' Annales, for example, a work that has been called the true Latin epic instead of Vergil's

7 Cf. Robertini/Giovini (2004, 258).

8 Cf. de Winterfeld (1902).

9 Cf. Jacobsen (1986, 2077-80).

10 Throughout this paper I will use the term 'epicity' in the sense of "the essence of being epic" and "the quality or state of being epic", as defined in the Urban Dictionary (https://www.urbandictionary.com/define.php?term=epicity). The term 'epic' has a specific meaning in Anglo-American slang and gave rise to the abstract term 'epicity', the definitions of which, however, fit in perfectly with the sense we need in order to distinguish the concrete epic writings from those elements that make up a work's 'epicness' or 'epicity'. These terms have already been used by Kaufmann (1988) or in the abstract of Mellmann (2017, 49-66), where the German 'Epizität' is translated as 'epicity', but without a justification for its appearance. 
Aeneid ${ }^{11}$ It displays a chronological development, the structure of which seems to have been as much determined by the historical sequence as by its poetic structure. And what might have been its narrative plot? The same might be asked for Naevius and even up to a certain degree for Ovid.12

Similar approaches that derive their criteria almost exclusively from a classicist reading in the end lead to a negative or restrictive tendency that possibly excludes all deviations from the ultimate Homeric and, to a lesser degree, Vergilian norm. This, however, causes new problems for all comparative literary studies. How can one still defend a transcultural - and as we will see also a transperiodical - approach when the norm is given and fixed by historically and culturally determined works? How, then, do we have to evaluate the epicity of the Babylonian Gilgamesh epic that predates the sources of a classicist normativity? ${ }^{13}$ Must we consider it 'primitive' for not having 'yet' attained Homeric plenitude? Moreover, what do the Mahabharata have to do with epic standards derived from a pre-classical Greek poem or from the Roman answer to it? And which appreciation should we give to the truly performative epics of African cultures as the Mwindo epic of the Nyanga?

In an even more complicated way medieval culture and literature both are and are not derivative of the classical model. Undoubtedly, we can discern a continuous attempt to fall back upon and restore classical norms and standards. Yet, simply this incessant tendency to restore or revive the long gone past betrays the consciousness of being different. Implicitly and explicitly this differentiation is constantly stressed and brought to the fore, which has its consequences for our understanding of medieval Latin epicity. We might compare it with the situation of the Japanese novel. As a form of literary expression the novel originates in Western European culture. Japanese writers adopted its form in the $19^{\text {th }}$ century and made it their own. They reinvented it into a purely Japanese literary form.

For similar reasons, in this contribution we take epicity in medieval Latin literature as a bi- or even multi-cultural form of literary expression. It inspired medieval, or better, contemporary reinventions of a form of literary expression as practised in antiquity. As we will see in this discussion, those reinventions did not result from any theoretical reflection, as would be more the case during the Renaissance, but from the immediate contact with a limited group of model

11 See Paquette (1988, 34): “En vérité, l'épique latin, c’est Ennius, non Virgile.” The reason for this remark is, indeed, Ennius' primacy!

12 The criterion of performance is of course the least applicable and loses almost all interest when regarding medieval or early modern epic, although reading aloud remained a common attitude for a long time even in modern times. I have touched upon this problem in Verbaal (2011).

13 Cf. Haubold in this volume on epic structures and narrative patterns in early Greek and Akkadian epic. 
texts that were intensively read, studied, copied, paraphrased, rewritten, and varied upon. Such an interpretation implies an evident rejection of any classicist standard by which to evaluate the epicity of a work. Epics as a genre cannot be considered the same in medieval and in classical literary culture. Generic elements lose their normative significance when exactly reinvention becomes the central way of reception. The epic materials out of which classical epics were constructed will help us get a better insight.

Before giving an overview of the concrete literary field that will be covered in this contribution, it seems necessary to develop further the above-made assertion on the way the Middle Ages themselves viewed the literary form that we might call 'epic'. What, according to medieval writers, gave a work its epicity?

There is no easy answer to this problem as theoretical reflection on literary genres is rare during the entire Middle Ages. This makes it difficult to have a clearcut view on what the medieval mindset considered to constitute an epic poem. The almost entire absence of theoretical reflection concerning literary form and genre may in itself of course be viewed as indicative of the attitude towards writing and literary forms, particularly because of the amount of theoretical reflection on other, more abstract fields in logic or theology. On the one hand, it seems to denote an approach less founded upon a conceptual approach to genre or literary expression than upon a practical approach, consisting of writing skills that continuously enter into a dialogue with model-texts. On the other hand, it might be evidence of the authority given to those model-texts as they were taught at school, implying somehow an interiorisation of their concrete characteristics as literary expression.

It does not mean, however, that during the Middle Ages theoretical reflection was entirely absent. Crucial texts from antiquity, notably from Late Antiquity, were well known and intensely studied. First among them was Isidore of Seville's Etymologies. ${ }^{14}$ In chapter 39 of the first book Isidore treats the different literary elements: meter, verse, rhythm, and poem. Meter is named after its feet, after its inventors, or after the subjects it treats. It is at this point that Isidore discusses the qualities of epic, although he nowhere mentions the word, preferring instead the traditional Latin denomination of heroic verse (Isid. orig. 1.39.9-11):

Heroicum enim carmen dictum, quod eo uirorum fortium res et facta narrantur. Nam heroes appellantur uiri quasi aerii et caelo digni propter sapientiam et fortitudinem. Quod metrum auctoritate cetera metra praecedit; unus ex omnibus tam maximis operibus aptus quam paruis, suauitatis et dulcedinis aeque capax. Quibus uirtutibus nomen solus obtinuit, ut heroicum uocaretur ad memorandas scilicet eorum res. Nam et prae ceteros simplicissimus habetur constatque duobus [pedibus], dactylo et spondeo, ac saepe pene uel ex hoc uel ex illo; nisi quod

14 Cf. Lindsay (1911). 
temperantissimus fit utriusque mixtura quam si instruatur a singulis. Omnibus quoque metris prior est.

Now, the heroic verse got its name because it is used to tell the exploits and conditions of strong men. For heroes are called those men that show themselves worthy of being of the higher regions and of heaven because of their wisdom and firmness. This meter surpasses all the other ones in authority. It is the only one that is as well fitted to the greatest topics as to the small ones, and has an equal capacity to please and to delight. Thanks to these virtues it is the only one that obtained this name, so that it is called heroic for remembering the histories of heroes. For it is also considered the simplest of all meters and it consists of only two feet, the dactyl and the spondee. Often it even consists only of either the one or the other, but the mixture of both gives it its perfect moderation, much more than when it is constructed with only one of both feet. It is also the first of all meters.

From Isidore, medieval poetics thus learned that epicity was characterised by the following elements: 1) it was written in heroic verse, i.e. in hexameters, consisting of dactyls and spondees; 2) it was used to treat heroic acts, i.e. the deeds of men that were considered heroes by virtue of their wisdom and strength; 3 ) it was the noblest and oldest meter, which was applied for the first time by Moses, but called heroic verse from the times of Homer onwards.

Isidore could be supplemented by a quotation from Servius' commentary on Vergil's works. In the prologue to his first book he gives some additional information (Serv. Aen. praef. 1.1.288): 15

Qualitas carminis patet; nam est metrum heroicum et actus mixtus, ubi et poeta loquitur et alios inducit loquentes. Est autem heroicum quod constat ex diuinis humanisque personis, continens uera cum fictis; nam Aeneam ad Italiam uenisse manifestum est, Venerem uero locutam cum Ioue missumue Mercurium constat esse conpositum. Est autem stilus grandiloquus, qui constat alto sermone magnisque sententiis. Scimus enim tria esse genera dicendi, humile medium grandiloquum. Intentio Vergilii haec est, Homerum imitari et Augustum laudare a parentibus; namque est filius Atiae, quae nata est de Iulia, sorore Caesaris, Iulius autem Caesar ab Iulo Aeneae originem ducit, ut confirmat ipse Vergilius a magno demissum nomen Iulo.

The quality of this poetry is immediately clear. For it is written in the heroic meter and contains a mixed action, in which the poet both speaks with his own voice and introduces other characters to speak. Now, it is heroic because its characters are both divine and human and thus it contains both truth and imagination. For it is obvious that Aeneas came to Italy, but it is definitely so that it belongs to the poetical composition to make Venus speak to Jupiter or to make Jupiter send Mercury. It is written in the grand style that consists of a high register and noble phrases. As we know, there are three ways of speaking: 1) the humble; 2) the middle; 3) the grand style. Vergil had the intention to imitate Homer and to praise Augustus by his forefathers. For he is the son of Atia, born from Julian descent, sister to

15 Cf. Thilo/Hagen (1881-1884). 
Caesar. Julius Caesar, however, derives his origin from Iulus, son to Aeneas, as Vergil himself attests: "the name derived from the great Iulus."

Besides the heroic meter, according to Servius, epicity consisted thus of: 1) what we would call a mixed narrative perspective, changing between the poet and the characters; 2) the intertwinement of the human and the divine, equated with truth and fiction; 3) the high style; 4) an artificial composition. Vergil's epic, for instance, was created in imitation of Homer and in order to praise Augustus. This last element highlights the openness to imitation and the laudatory aspect that will become an important feature of medieval epicity.

What can be deduced from these two normative prescriptions, remains in reality rather limited. Medieval epicity, in any case, applies the hexameter as the epic verse, which is considered to belong to the high style. This elevated style, however, can be stressed by other means, very often the use of complicated and hermetic vocabulary or phrasing. It treats heroic deeds that combine acts of strength and courage, and of wisdom. For that reason, the medieval hero need not be a military warrior, but he can also be a saintly warrior, a miles Christi. There is thus no reason to deny a priori epicity for the multitude of hagiographic poems. On the contrary, saints appear over and over again as the true and only heroes, worth praising or imitating.

Even more important for the understanding and interpretation of medieval epicity than classicist categories are therefore the ultimate models that gave authority to the writing of epic poetry. Vergil of course is fundamental for the epic register, the form, the content, and the artificial composition. This does not mean that medieval epicity implies an absolute fidelity to the example set by the poet from Mantua. On the contrary, medieval epicity rather seems to deviate consciously and constantly from this ultimate model, but it rarely does so without being conscious of it. Once again, this points towards an active dialogue with the authoritative models. Next to Vergil, authority is given to Lucan for historical epic, ${ }^{16}$ to Ovid ${ }^{17}$ and Statius for mythological epic (even though Statius was predominantly considered a historical poet), to Juvencus, Sedulius, and Arator for biblical epic, ${ }^{18}$ to Prudentius for allegorical epic, and to Venantius Fortunatus for the hagiographic epic.

The considerable presence of Christian epics in Late Antiquity that perhaps is too often neglected in scholarship has an important consequence as to Servius' characterisation of classical epicity concerning the intertwinement of truth and fiction. It may be clear that his equation of fiction and divine intervention could

16 On historical epic, see Nethercut in volume I.

17 On Ovid's Metamorphoses, see Sharrock in volume I.

18 On Greek and Latin biblical epics, see Verhelst and Schubert in this volume. 
not be disjointed from the other elements. In the wake of Juvencus and the other Christian poets, high style and heroism got into conflict with the openly confessed presence of fiction or 'lies'. Christian epicity from its beginning stressed the truth of its contents. This remains a central theme during the entire Middle Ages. Supernatural interventions, for that reason, are almost entirely absent, not only in their mythological sense but even in a Christian way. Gods, devils, and angels rarely appear in medieval Latin epic; saints do - but they represent the prototypical medieval 'hero', with humans performing great deeds by their wisdom and strength (of faith).

Even with these very general characteristics an approach to medieval epicity has to remain careful and may not apply them in an all too strict way. Notably, Ovid's growing popularity in the course of the $11^{\text {th }}$ and $12^{\text {th }}$ centuries coincided with (and perhaps partly put into motion) a completely inverted approach to the classical tradition. As we will see, even the hexameter lost its priority as the stock meter of epicity. Even before, humour and especially burlesque humour entered epic poetry and were no longer seen as contrary to the high style and dignity of classical epicity. In vernacular epic this burlesque element seems to have been part of the epic tradition almost from the beginning. The heroic, however, has always remained central. This changed with the rise of the animal epic where humour became the content of the poem itself and the heroic disappeared entirely.

The importance of the humoristic aspect may give an indication that even the tension between truth and fiction was less severe than one might suppose. In fact, the truth claims by the poets and in the poems became more pressing during the $12^{\text {th }}$ century when the fictional elements in literary works increased, both inside and outside poems with epic ambitions.

For all these reasons, in this contribution I adopt an open definition of medieval Latin epic: I am not excluding poems for formal or classicist reasons, and I rather take into account those poems that seem to adhere to the 'heroic' tradition or that strive to do so. Simultaneously, I will attempt to identify when the structural elements that make up medieval epicity start to prevail and when they start to lose their self-evidence, giving way to new interpretations of what ought to make an epic poem.

\section{Demarcation of an open field: medieval epics}

As the field of medieval Latin epicity remains such a blank spot within both the literary tradition and classical scholarship, it seems rather necessary first to give an outline of the field that this contribution wants to cover. It cannot be the intention 
to list all the works that in one way or the other might qualify for an epic statute. I rather want to set temporal boundaries and demonstrate how it cannot be possible to draw strict borders, separating medieval epicity from either classical or humanist epicity.

Traditionally, the fragmentary poem De Karolo rege et Leone papa (dated around or just before 800), ${ }^{19}$ formerly ascribed to Angilbert, is taken as the first medieval Latin or even medieval epic. ${ }^{20}$ Schaller's reasons are: 1 ) it is based on indirect allusions by the poet, to be taken as a third book, thus betraying a more extended poetical project; 2) it displays the typical elements of written epic (epic broadness, detachment from actuality, character speeches, a bee-simile, a Vergilian dream vision etc.). ${ }^{21}$ He therefore characterises the poem as a panegyric epic in honorem Karoli.

Without denying the validity of this analysis and characterisation, one notices at a single glance, once again, the classicistic inspiration of these criteria. The sole mention of a Vergilian dream vision reveals the almost preconditioned decision, either conscious or unconscious, to take the classical model par excellence as the norm to which later authors had to conform in order to achieve epic qualities. In the background lurks the classical hierarchy that assigns the highest position to epic. Medieval Latin poems that strove for epicity thus had to conform to the rules as laid out by the 'epic of all epics': Homer and, in a derived form, Vergil.

This attitude, however, imposes a very restrictive frame upon medieval poetics, denying it all proper inspiration and, even more, any proper aspirations - as if medieval epicity can only be recognised when it demonstrates the utmost submission to its models and thus limits itself to strict imitation. Certainly, during the medieval period, poems have been written that displayed these imitative characteristics and that remained closer to the classical models, but, as we will see, these poems were typical products of school exercises. Poets who wanted to be poets in their own right had to break away from simple imitation to find new ways, even when their work was always founded upon what they had learned at school.

19 Cf. Dümmler (1881b).

20 Cf. Schaller (1983, 1044-5), Tyssens (1988, 42), Schaller (1989, 368), and Schaller (1993, 26).

21 Cf. Schaller (1983, 1044): “epische Breite, Aktualitätsferne, behagliche Schilderung, Redeszenen, Bienengleichnis, vergilianische Traumvision usw.” 


\subsection{Beginnings?}

A poem that became one of the first victims of this classicist approach to medieval poetics is Aldhelm of Malmesbury's De uirginitate, composed before $690 .{ }^{22}$ This poem is almost entirely absent from scholarship on medieval Latin epics, or, if mentioned, it is often discarded as merely a paraphrase of the prose text by the same writer. ${ }^{23}$ The poem De uirginitate was nonetheless the first carmen that achieved 'epic' length at the start of the new era. ${ }^{24}$ It counts 2904 hexameters and comprises a prologue of 38 lines. Aldhelm's most important literary models were Vergil, Juvencus, and Sedulius. ${ }^{25}$ It is especially noteworthy that Aldhelm followed Juvencus in his renunciation of the classical epic invocation of the Muses and/or Apollo, whom he replaced by an invocation of the Trinity.

The objection to calling his poem an 'epic' thus seems closely linked to its dependence on Juvencus and on Aldhelm's own prose work. This second argument that Aldhelm's poem is but a paraphrase, however, also applies for Juvencus himself who is all too often discarded as an epic poet in his own right. ${ }^{26}$ I will return to the paraphrase as an important aspect for the understanding of medieval poetics later in this contribution. For the moment let it suffice to say that as much as Juvencus' entire approach wants to redefine Vergil's idea of epic by writing the new Christian epic, Aldhelm in his fidelity to both Vergil and Juvencus can be considered a Christian poet who in his De uirginitate seeks to write an epic poem.

Aldhelm mentions twice, once in the prose and once in the metrical version of his De uirginitate (20), that the poem is written in the heroic verse. ${ }^{27}$ Elsewhere, in his metrical treatise De metris et enigmatibus ac pedum regulis (10), he defines this verse himself as follows: ${ }^{28}$

Qui sund exametri heroici? Qui bella et heroum res gestas complectuntur, ueluti est Ilias Homeri uel Aeneidos Vergilii uel <libri> Lucani proelia Caesaris et Pompei decantantis.

22 Cf. Ehwald (1919c).

23 Cf. Ehwald (1919d).

24 Periodisation always poses a problem, but this is not the place to open up the discussion. Aldhelm, however, can be seen as one of the first writers whose link with antiquity and with Latin letters is exclusively based upon his school education. While this will become the 'normal situation' for medieval Latin epicists, it is not yet entirely valid for writers from the Vandal Kingdom of North Africa or from the Visigothic Kingdom in Spain at that time. See Lapidge (1979, 209-10). 25 Cf. Orchard (1994, 225-38).

26 Only very recently Juvencus seems to enjoy a scholarly rehabilitation, of which McGill (2016) may be an indication.

27 Cf. Ehwald (1919c, 249) and Ehwald (1919d, 353).

28 Cf. Ehwald (1919b, 83). 
What are heroic hexameters? They contain the wars and deed of heroes, like Homer's Iliad or Vergil's Aeneid or Lucan's books on the battles between Caesar and Pompey.

By referring to the metre of his own poem as heroic verse, he links it explicitly to the classical epic models. This is confirmed by his other important poem, the Aenigmata. It forms part of this same metrical treatise but is clearly separated from the rest of the treatise as a distinct element. ${ }^{29}$ The Aenigmata has its own invocation, similar to the one of Aldhelm's De uirginitate, but it contains 36 verses. When asking God for help and inspiration to fulfil his poem, he describes it as written ritu dactilico without any mention of the heroic verse. ${ }^{30}$ Aldhelm thus makes a clear distinction between the heroic approach of his poem on saintly virgins and the didactic approach of his riddles.

Regardless of our modern conception of what makes an epic, Aldhelm placed his poem De uirginitate in the literary tradition that, for him, effectively started with Vergil and found its ultimate models in Juvencus and Sedulius, the Christian poets of Late Antiquity. According to Aldhelm himself, as part of the heroic tradition, his poem therefore has to be considered an epic, as opposed to the prose version of his De uirginitate and the Aenigmata. For the moment, the question about what makes up the poem's epicity shall remain open, an answer will, however, be suggested later.

Aldhelm's example was of crucial importance for two other poems that belong to this pre- or early Carolingian period, Bede's Vita Sancti Cuthberti ${ }^{31}$ and Alcuin's Versus de patribus regibus et sanctis Euboricensis Ecclesiae. ${ }^{32}$ Both are rarely mentioned in studies on medieval Latin epics. Yet, both show the immediate influence of Aldhelm and each seems to continue his strain of thought. Bede's Vita is a modest poem of 941 hexameters, preceded by a prologue of, once again, 38 lines. The link to Aldhelm's poem is thereby suggested and indeed: What is Bede's poem if not the poetical rephrasing of the life of a saint? But while Aldhelm used an entire catalogue to illustrate his plea of virginity, Bede focuses on one particular saint, after the model of Venantius Fortunatus' Life of Saint Martin. Just like his predecessors, Bede wants to sing of the deeds of his saint ${ }^{33}$, and he wants to do

29 Cf. Ehwald (1919b, 99-149).

30 Aldhelm, De metris et enigmatibus ac pedum regulis, praef. 27. Cf. Ehwald (1919b, 98).

31 Cf. Jaager (1935).

32 Cf. Dümmler (1881a).

33 See Beda, Vita Sancti Cuthberti metrica, prologue: "Unde tibi uel ad memoriam meae deuotionis uel ad tuae peregrinationis leuamentum beati Cuthberti episcopi, quae nuper uersibus edidi, gesta obtuli ... Scire autem debes, quod nequaquam omnia gesta illius exponere potui ..." 
so in heroicis uersibus. ${ }^{34}$ Both Aldhelm and Venantius denote the subject of their poem, or, in Aldhelm's case, poem and prose treatise, as the gesta of their saints. Their ultimate source was Juvencus who in his prologue substitutes the deeds of the pagans by those of Christ, replacing classical epic with a new Christian epic. ${ }^{35}$

In his poem on the church of York Alcuin refers to Bede's poem as treating the deeds of the Saint (Versus 740-3). Moreover, he states that Bede's poem is written in the heroic verse (Versus 684-6), thus adopting Bede's own characterisation of his poem in both the prologue to his prose version and the catalogue of his own works at the end of his Historia Ecclesiastica. ${ }^{36}$ As both references are incorporated in his own long poem are used as an excuse for not having to expand too much himself on the life of Cuthbert, Alcuin suggests that he adheres to his predecessor and to the tradition to which he belonged.

With Alcuin we feel already more on familiar ground. The language of his poem immediately sounds familiar. Whereas Aldhelm still rejoiced in the Hibernian exuberance in spite of his reaction against it, Alcuin's language conformed to modern ideas of the classic: it is simple, straightforward, and clear. Also, Alcuin is a better poet than Bede, whose verses give a more forced impression. His language resounds with familiar classical echoes, notably with Vergil. Alcuin's poem, moreover, seems to conform to the aforementioned imposed criteria of epicity: narrative unity, epic broadness, and textual extension. With 1657 lines, it ranks in the middle between Bede's and Aldhelm's poems. Compared to Aldhelm, it exploits the possibilities the epic models offer much less. Similes and comparisons are rarer, and there is less figurative language.

The poem mostly retakes Bede's text of the Historia Ecclesiastica, but makes a strong selection and orders the chosen fragments anew, thus creating a more unified chronological narrative until the year 721 when the poem leaves Bede behind and continues its own story (Alcuin, Versus 1215). It is from this part onward that the poem's epicity, even in its classical elements, increases. It contains an apostrophe to the hermit Baldred (1318-23), opening with a strongly Vergilian

34 Cf. Beda, Historia Ecclesiastica 4.26 and 5.24; see also the prologue of Vita Sancti Cuthberti (prose).

35 See Iuvenc. praef. 15-20 Quod si tam longam meruerunt carmina famam, / Quae ueterum gestis hominum mendacia nectunt, / Nobis certa fides aeternae in saecula laudis / Inmortale decus tribuet meritum que rependet. / Nam mihi carmen erit Christi uitalia gesta, / Diuinum populis falsi sine crimine donum. In itself the use of gesta was very common, notably in historiographical writings, but its epic use in the Christian models gave it a more specific ring, denoting the historical truthfulness of the Christian epicity as opposed to the pagan epicity.

36 Remarkably Alcuin maintains that Bede first wrote the prose and afterwards the metrical version. Bede himself asserts that he first wrote the metrical life and later the more expanded prose version. It seems as if Alcuin is mixing up Bede's double version with that of Aldhelm. 
reminiscence, several elaborated ekphraseis of altars, the new basilica at York (1487-534), the library with its content (1540-56), and the shipping metaphor for the poetic endeavour (1648-50). The writers' catalogue in the passage on the library illustrates that the poem follows a clear compositional concept. The central verse mentions Aldhelm and Bede, Alcuin's own models. Moreover, this line separates the preceding Church Fathers from the following classical pagan and Christian authors. There seems to be no reason to dispute the poem's epicity, not even on classicist grounds!

From the many differences between Alcuin's Versus de patribus regibus et sanctis Euboricensis Ecclesiae and the fragmentary poem De Karolo rege et Leone papa, which was written hardly two decades later, the following questions arise: Do we have to consider these contrasts as an indication of their affiliation to different genres - one epic, the other not? Or do we have to deal with a distinct functionality for each - one designed for an ecclesiastical, the other for a courtly context? In that case, we may suppose a functionalisation of the epic genre that infringed upon its supposedly fixed imperatives. As a matter of fact, this attitude of imposing new criteria unto the classical form (and norm) was maintained during the entire period of the Middle Ages and helps us understand the poetics of medieval epicity.

\subsection{Endings?}

Traditionally, Walter of Châtillon's Alexandreis ${ }^{37}$ and Alan of Lille's Anticlaudianus, ${ }^{38}$ both composed around 1180, are referenced as the last Latin epics of the Middle Ages. ${ }^{39}$ When these poems are not analysed on their own but within their literary context, it, however, becomes clear that both poems in fact belonged to a revival of epic poetry and the epic tradition, in the broad sense of the definition, which did not come to a close with them.

The most obvious example is the Iliadis by Joseph of Exeter, ${ }^{40}$ which was roughly contemporaneous and ridiculed together with the Alexandreis by Alan of Lille in his Anticlaudianus (1.165-70). Yet, there are lot more examples such as the royal verse panegyrics, the Ligurinus by Gunther for the court of the emperor

37 Cf. Colker (1978).

38 Cf. Bossuat (1955) and Chiurco (2004).

39 A reason for this assessment is often absent from the handbooks and studies on medieval Latin epic. Not even Schaller (1989) explains what makes him consider the Alexandreis and the Anticlaudianus to be the last representatives of medieval Latin epic.

40 Cf. Gompf (1970) and Mora (2003). 
Henry VI (in the 1180s), ${ }^{41}$ the Draco Normannicus by Stephen of Rouen for Henry II of Normandy and England (just before 1170), ${ }^{42}$ the Carolinus by Gilles of Paris (around 1200), ${ }^{43}$ and the Philippis by William the Breton (around 1220), both for sons of Philip II, known as Philip Augustus, the King of France, ${ }^{44}$ as well as ecclesiastical panegyrics, for instance, the Legenda Sancti Francisci uersificata by Henry of Avranches (before 1250) ${ }^{45}$ or De triumphis Ecclesiae by John of Garland (around 1250), as well as a still continuing flow of hagiographic epics. ${ }^{46}$ Alan's allegoric epic was followed by the Architrenius of John of Hauville (in the 1180 s) ${ }^{47}$ and the more recent subtype of courtly and knightly romances such as the Gesta militum by Hugh of Mâcon (around 1250). 48

The decades before and after the year 1200 thus seem to have offered a huge revival of Latin epic poetry that makes it only the more urgent to reconsider the prescriptive criteria applied to them. Are they epics or not? Mostly their epicity is denied because of their being 'just' a poetical paraphrase of a prose text, ${ }^{49}$ being too varied and careless in regard to the traditional, i.e. classical, models, ${ }^{50}$ or more of "a satura lanx swollen to epic dimensions, and not an epic poem." ${ }^{11}$ At the same time, however, few of them could escape the influence of the Alexandreis and the Anticlaudianus, the two poems whose epicity is widely recognised. What then makes the Philippis, the Architrenius, or the Legenda Sancti Francisci uersificata less epic than the models that inspired them? Is it only the fact that these poems are no longer classical models? Yet, it is exactly this replacement of the classical poets with contemporaneous models that would go on to become one of the most characteristic features of the literary revolutions that took place during the long $12^{\text {th }}$ century.

In order to understand the unwillingness of modern scholarship to acknowledge the epicity of the poetry composed from the late $12^{\text {th }}$ to the mid-13 $3^{\text {th }}$ century,

41 Cf. Assmann (1987).

42 Cf. Howlett (1885).

43 The unedited text is avaible online: https://gallica.bnf.fr/ark:/12148/btv1b9066816f?rk=21459;2.

44 Cf. Delaborde (1885).

45 Cf. Cremascoli (1995).

46 Cf. Wright (1866).

47 Cf. Schmidt (1974).

48 Cf. Könsgen (1990).

49 Cf. Schaller (1989, 30-1) on the Ligurinus.

50 Cf. Schaller $(1989,31)$ on the Draco Normannicus.

51 Schaller $(1989,41)$ on the Architrenius. Let it be said that Schaller is the only scholar who accounts for the fluid nature of medieval Latin epicity. I do not want to criticise his attempts, but rather show how these are preconditioned by his classicist perspective and for that reason do not teach us about the poetics of these medieval Latin poems in their own right. 
we have to look in another direction. Petrarch's Africa (1338-1374) is hailed as the first epic of the new humanistic age that finally "after eight centuries of neglect wants to reanimate the high epic genre." 52 And, indeed, when reading Petrarch's magnum opus, one immediately recognises the classical inspiration. His language, poetics, and subject matter all reflect the Vergilian mode in a much stronger way than any of the poems previously mentioned. All the traditional classical structures and motifs reappear in Petrarch's Africa: dreams, catalogues, embedded narratives, battle scenes, even a katabasis. So, in a classicist sense, we certainly returned to the ancient way of writing epic.

However, Petrarch never managed to finish the Africa. He seems even to have let go of the entire project in the end. ${ }^{53}$ This surely was not due to Petrarch's incapacity, but it may be attributed to the incompatibility of the entirely classical world of the poem and Petrarch's contemporary surroundings. The initial success of the poem was probably more due to the fame of the poet himself than to a true appreciation of the work as such. Its reappraisal dates back hardly more than a century. Nonetheless, Petrarch showed other poets a new way they could follow in their compositions by reviving classical poetics. Boccaccio's Teseida (1340-1341) is both the first response to Petrarch's revival of the classical models and a very different take on it. ${ }^{54}$ Boccaccio's story tells of knightly and courtly love and remains thus more in the tradition of Chrétien's romances than Petrarch's historical epic. He only puts his story in a classical frame. More successful as a Latin equivalent were Ugolino Verino's Carlias (1489), 55 which transposed the chanson de geste into a classical form, and Girolamo Vida's Christias (1535). ${ }^{56}$

Petrarch's Africa cannot be disconnected from what we see happening in the second half of the $13^{\text {th }}$ century. Latin narrative poetry more or less came to a standstill as prose narratives took over, such as Guido delle Colonne's Historia destructionis Troiae (before 1290), ${ }^{57}$ which to a large extent rewrote Benoît de Sainte-Maure's Roman de Troie (before 1160), or Rolandino di Balaiardo's prose narrative on the life and death of Ezzelino da Romano (before 1262). In the prologue to his work, entitled Cronaca, the author explicitly justifies his choice of prose

52 Lamarque (2002, 10-11). See also Festa (1926) and Lenoir (2002).

53 Cf. Ellis $(2007,3)$.

54 Cf. Roncaglia (1941) and Agostinelli/Coleman (2015).

55 Cf. Thurn (1995).

56 Cf. Gardner (2009).

57 Cf. Griffin (1936). 
over verse as the more suitable medium for storytelling. ${ }^{58}$ Yet, he links his prose account explicitly to the classical epics. Similar prosaic rewritings became the more common narrative form in the $14^{\text {th }}$ and $15^{\text {th }}$ centuries, both in Neo-Latin epic and in the European vernacular traditions, before or parallel to the humanistic return to classical poetics. One might conclude that medieval Latin epic ended with this current of prose rewriting, while epic as poetry continued in the vernaculars.

\section{Deconstructing classical epicity}

Now that we have established that the beginning and the end of the literary tradition of medieval Latin epic was less demarcated and more open and fluid than widely assumed, it can be inferred that the period in-between was all but homogenous or uniform. This is of course a problem for all generic approaches to medieval literature: whereas genres are more or less clearly defined and categorised in antiquity and Renaissance humanism, medieval poetics seem to have rejected any attempt to make them adhere to these (classical) restrictions.

The omission of categorical epic definitions, however, does not automatically mean that authors did not place their works in the existing and acknowledged tradition. They carefully chose which of the traditional epic structures and motifs to include, change, or avoid. Vergil, Lucan, and Statius remained the most important school authors during the six centuries that link Aldhelm to Guido delle Colonne. They were common knowledge for all poets writing in this period. If they chose not to follow them, it was a deliberate decision to deviate from the classical model.

For that reason, we will analyse more profoundly on what bases similar choices may have been founded in order to determine which structural elements are constitutive of medieval Latin epicity. For the moment, two remarks may suffice: firstly, medieval Latin literature, perhaps even medieval literacy as a whole, was a product of schools and formal education. This included more than just the ability to read and write, it entailed an entire mindset and frame of reference. Latin was, first of all, not so much the language of the ancients, but the language of the schools; writing in Latin therefore meant to express oneself in the ways taught at school. Imagination, reasoning, and expressing oneself all had to be done in this second language, not one's native language. Vergil and the other classical authors taught at school shaped the students' minds. Every word referred to the classical models

58 Rolandino, Cronaca, prologue: Scribo quoque prosayce hac de causa, quia scio que dixero posse dici a me per prosam plenius quam per uersus, et cum sit his temporibus dictamen prosaicum intelligibilius quam metricum apud omnes. Cf. Fiorese (2005, 14). 
first before referring to an extra-scholastic or even extra-textual reality. Every author of Latin literature in the Middle Ages had to come to terms with the burden he took with him from the classroom. Not only did these school authors provide a well-known corpus of literary motifs and stock phrases, but they also served as authorities that prescribed what could be done written and how it should be written.

The second compelling factor was liturgy. Latin was the language of the Church, notably of liturgical practice. Still more important than Vergil were the psalms that were sung during Mass, in which the voices of the faithful joined with the voice of God. The importance of the liturgical impact on the medieval mindset is all too often ignored or underestimated in literary studies on this period: it made Latin the language of the divine and thus of truth.

Writing in Latin for the medieval author - and for most of this period he did not have another written language - meant that he had to find his way between the language of teaching and its prescriptive truth, and the language of faith and its absolute truth. In both cases, however, Latin remained the language of truth. Writing in Latin thus implied writing truth and, indeed, fiction in medieval Latin only appeared late, apparently as a result of the emerging vernacular languages that had no such impediments to the creation of fictitious or untruthful worlds.

As regards epicity, some traditional structures did not appear in medieval Latin epics because they were considered untruthful and were conflicting with the general, common mindset of the period. Most obviously, this applies to the 'divine machinery' of the epic tradition, especially divine interventions. As to the omission of pagan deities, their absence comes as no surprise and needs no further explanation. Already in late antique Christian epic they were considered to be simply fictitious deceptions. For that reason, they did not create any problems and their names and images were freely used as every reader was presumed to understand their metonymic function.

More remarkable is the almost entire absence of all divine interventions. In medieval Latin epic superhuman or religious characters only very rarely get involved in the events on the mortal sphere. There are two exceptions: one will become clear later when we discuss one particular deconstructed application of classical structures, the other is the depiction of saints in hagiographic epics. They of course conform to the medieval understanding of Isidore's and Servius' definition of what ought to be the subject of the heroic verse, i.e. heroic acts, the deeds of men that were considered heroes by virtue of their wisdom and strength. Saints were these types of mortal heroes and they conformed even more to the definition than pagan heroes as they gained victory over mortal opponents as well as spiritual ones, and not only through their physical strength, but also through the force of their wisdom. 
Truthfulness, however, was not the only reason for the disappearance of classical structures from medieval epicity. In his poetic treatise, Ars uersificatoria (before 1175), the first full-length practical manual for writing poetry since antiquity, Matthew of Vendôme disapproves of the use of similitudines and comparisons. ${ }^{59}$ According to his view, the ancients needed these to fill their plot and storylines as they lacked material and technique. The moderns ought not to make similar mistakes (Ars uersificatoria 4.4-5):

4 Non quia comparationem inductio penitus sit omittenda, sed parcius a modernis debet frequentari; poterit duci, quia scema deuiat sine istis et nunc non erit hic de iis opus.

5 Antiquis siquidem incumbebat materiam protelare quibusdam diuersiculis et collaterlatibus sententiis, ut materiae penuria poetico figmento plenius exuberans in artificiosum luxuriaret incrementum. Hoc autem modernis non licet. Vetera enim cessauere nouis superuenientibus.

[We do not say] that the incorporation of comparisons completely has to be omitted but moderns have to apply it more sparingly. They can be introduced because, without them, the poetic scheme falls short, but now and here we need not speak of them.

Indeed, the ancient poets were inclined to protract their subject by all kind of trifles and irrelevant phrases so that the poor subject became enrichened by poetic imagination and abounded in artful additions. This is no longer permitted to modern poets. What is old has to recede when the new takes over.

Matthew of Vendôme's remarks demand our attention. They leave no doubt at all that he and his fellow poets were conscious of the importance that comparisons and similitudines had for the epicity of classical poetry. He did not forbid his contemporaries to use them at all, but instructed them to make careful use of them, as they diverted from the main theme (Ars uersificatoria 4.3 collateralia quae non sunt de principali proposito). Modern taste, i.e. the poetic sensibility of the second part of the $12^{\text {th }}$ century, preferred and expected the poet to stick to his theme. The contemporary poet had to keep to the 'truth' of the story and try not to wander off. Comparisons and similitudines were taken as gap fillers, unnecessary for a poet who strove for completeness combined with brevity. Does this not contradict the requirement of epic broadness, taken by modern scholars as one of the conditions to make a poem 'epic'? It would, indeed, if comparisons and similitudines were the only structures to expand the poem. Medieval poetics, on the contrary, seemed to prefer the description as a broadening element.

59 Cf. Munari (1988). 


\subsection{Storms}

If a wish for truthfulness and coherence might be traced back to the schools, the same argument does not apply for all the missing elements from classical epicity. Some must be due to other reasons. I want to illustrate this by way of one of the most conspicuous absences in medieval epic: the storm scene. Storm scenes appear in all of the classical epics the medieval poet knew from school, even in Ovid, ${ }^{60}$ and since Vergil they play a crucial role in the development of the plot. ${ }^{61}$ In medieval epicity storms have lost their importance and are completely absent. They reappear in the romans d'antiquité (between 1150-1170), which are stricter rewritings of ancient texts. From thence they may appear in the roman courtois, but they disappeared entirely from poems that seem to adhere to the epic tradition.

The medieval refusal to recreate ancient epic storm scenes becomes most clear at those moments where the topic spontaneously almost offers itself as part of the storyline. Walahfrid Strabo's Visio Wettini (after 824) is a good example for this tendency. When describing the embassy of the former abbot of the Reichenau, Heito, to Constantinople, ${ }^{62}$ Walahfrid strikingly limits the description of Heito's shipwreck to only four verses (Visio Wettini 71-4):

\footnotetext{
Dirigiturque maris trans aequora uasta profundi

Graecorum ad proceres, scopulisque illisa carina

Fudit onus cunctumque uirum, sed praesul ab undis

Seque suosque manum domino praebente recepit.
}

He made for the Greek emperors over the vast field of the profound sea. The ship broke upon the cliffs and threw out its charge and every man, but, thanks to the Lord, our bishop saved himself and all his men from the waves.

This brevity has nothing to do with the poem being a paraphrase of the prose account that Heito himself made of Wetti's vision, for Heito did not mention his own embassy. Walahfrid introduced this episode as part of his history of the monastic island of Reichenau that serves as the introduction to the actual paraphrase. He clearly wanted to follow in Alcuin's footsteps.

Nonetheless, Walahfrid did not seize the opportunity to elaborate a topic that was well known to him from his ancient models. It may be remembered that he got the nickname Honoratus after the Vergil-commentator, Servius Honoratus, for his excellent familiarity with the Roman poet. Why then should he not have given a nice sample of his competence as an epic poet when the opportunity presented

\footnotetext{
60 Cf. Bate (2004).

61 On storm scenes in classical epic, see Biggs/Blum in volume II.2.

62 Cf. Dümmler (1884d).
} 
itself? After all, he hoped to make an impression on Wetti's relative, Grimaldus, with the poem in order to obtain his protection. The only explanation is that he was not at all interested in this particular epic structure.

Strangely enough, storms scenes are also absent from the much later Alexandreis, although the poem is widely considered, as mentioned above, to have revived the norms and many of the structures of classical epic. For that reason, the absence is even more striking and puzzling because the poem almost seems to demand it. At the end of Book 9, Alexander the Great sets out on the Ocean with his companions (Walter of Châtillon, Alexandreis 9.578-80):

Dixit et ad naues socios inuitat. at illi

Ducat eos quocumque uelit, hortantur, et ecce

580

Nauticus exoritur per fluminis ostia clamor.

He spoke these words and then he invited his companions to the ships. They urged him to lead them wherever he wanted and, look, the shouts of the crew arose from the river's estuary.

He returns quietly in Book 10 (Alexandreis 10.168-70):

\footnotetext{
Iamque reluctantem Pelleus classe minaci

Fregerat Oceanum, iamque indignantibus undis

Victor ab Oceano Babylona redire parabat.
}

With his threatening fleet, the man from Pella had already broken the resisting Ocean. Victor over the scandalised waves, he prepared to return from the Ocean to Babylon.

In the 167 verses between the two passages quoted above the personification of Nature, shocked by Alexander's haughty claim that the world will prove too small for his ambition and army, sounds the alarm in the underworld and mobilises the forces of hell to stop him. They are not inclined to evoke a storm, although the opportunity presents itself, and decide to poison Alexander instead. As the entire Tartarus scene is a genuine invention of Walter of Châtillon, Curtius Rufus cannot offer an explanation for the omission of the storm scene in his model. Even in view of the requirement for truthfulness, the storm scene would fare better than the somehow unnecessary staging of Nature and hellish demons, just to obtain a deadly poison as an alternative mode of death. This may have been one of the aspects that drew criticism from Alan of Lille in his Anticlaudianus (1.166b-70):

illic

Meuius in celos audens os ponere mutuum,

Gesta ducis Macedum tenebrosi carminis umbra

Pingere dum temptat, in primo limine fessus

170

Heret et ignauam queritur torpescere musam. 
There, Mevius dares to raise his mute voice toward the heavens, while he tries to paint the deeds of the Macedonian general with the dim shadow of his poem. He halts even on the threshold and complains that his idle Muse grows numb.

In his own poem Alan showed how one had to treat a scene in hell and what reasons one had to introduce such a scene. Yet, in the Anticlaudianus, a storm scene does not occur either. Alan does not need it for his story.

The medieval avoidance of the storm scene might have another origin: in Juvencus' Historia Euangeliorum, a storm does occur when Christ and the disciples pass over the Lake of Gennesaret. It is elaborated as an obvious paraphrase of Verg. Aen. 1.81-143, but its effect is rather different, as Christ wakes up, calms the waves, and reproaches his disciples for having too little faith (Iuvenc. 2.25-42):63

25 Conscendunt nauem uentoque inflata tumescent

Vela suo, fluctuque uolat stridente carina.

Postquam altum tenuit puppis, consurgere in iras

Pontus et inmissis hinc inde tumescere uentis

Instat et ad caelum rabidos sustollere montes;

30 Et nunc mole ferit puppim nunc turbine proram, Inlisosque super laterum tabulata receptant Fluctus disiectoque aperitur terra profundo. Interea in puppi somnum carpebat Iesus. Illum discipuli pariter nautaeque pauentes

35 Euigilare rogant pontique pericula monstrant. Ille dehinc: 'Quam nulla subest fiducia uobis! Infidos animos timor inruit!' Inde procellis Imperat et placidam sternit super aequora pacem. Illi inter sese timidis miracula miscent

40 Conloquiis, quae tanta sibi et permissa potestas, Quodue sit imperium, cui sic freta concita uentis Erectaeque minis submittant colla procellae.

They embarked, the wind bellied out the sails and the ship flew over the droning breakers. As soon as the boat reached the open sea, the waves rose in anger, the winds were set free, made them swell and menace, and heaved them up to the sky as enraged mountains. Now it hit with all its weight the stern, then it attacked with a whirlpool the prow. Over both sides, the freeboards received the blows of the breakers. The depth broke asunder and the ground became visible. In the meantime, Jesus was asleep on the stern. Terrified, his disciples and the crew asked him to wake up and showed him the dangers of the sea. He said to them: "Is no faith in you left? Fear has only a grip on unbelieving minds.” Then he gave orders to the storm and a quiet peace lied down on the waters. Intimidated, the others mentioned to each other the miracle. What huge power had been permitted to him? What was his dominion, who put to the yoke the waters stirred up by the winds and the storms menacing from above?

63 Cf. Huemer (1891) and Canali (2011). 
As the composition of Latin literature in the Middle Ages (and other periods) involved, first of all, the dialogue with other texts, and Juvencus was just as important as a model to the medieval poet as Vergil, it seems that the absence of sea-storms in medieval epicity might have been a result of Christ's eternal taming of the waves.

\subsection{Catalogues}

Not all absences of epic structures, however, are true omissions. Many of them simply take on new forms and importance. Let us have a closer look at two structural elements from classical epic that seem to have reappeared in entirely different forms, making them very hard to recognise. Yet, as such, they are able to uncover some of the fundamental processes that determine medieval epicity.

The first structure is the epic catalogue. Since the Iliad catalogues have been considered to be one of the core structures of classical epic, in spite of their absence from the Odyssey. ${ }^{64}$ Roman epics delight in listing all kind of topics, and especially Ovid's poems contain marvellous examples. Iliadic catalogues of troops can also be found in Vergil, Lucan, and Statius, so no medieval poet could be unaware of them.

In the Gesta Berengarii imperatoris (around 915) the second book contains an elaborate catalogue of the army of Berengar in the description of the Battle at Brescia (888). ${ }^{65}$ Perhaps around this same period, the Waltharius was written. Almost a third of the story consists of Walther fighting and killing, one by one, the eleven knights of King Gunther (Waltharius 640-1061). Their names are only provided when they come forward to confront the hero. Each knight is characterised briefly, mostly prior to the fight, some, however, also after the duel has already started. This turns these confrontations into a mixture of catalogue descriptions and battle scenes, but the cataloguing aspect is reinforced at the end when only four knights are left with the king (1007-11):

Nomina quae restant edicam iamque trahentum:

Nonus Eleuthir erat, Helmnod cognomine dictus,

Argentina quidem decimum dant oppida Trogum,

1010 Extulit undecimum pollens urbs Spira Tanastum,

Absque Haganone locum rex suppleuit duodenum.

Now I will give the names of them who remained and were prepared. The ninth was Eleuthir, who was also called Helmnod. The town of Strasbourg had sent Trogus as the tenth. The

64 Cf. Reitz/Scheidegger Lämmle/Wesselmann in volume I.

65 Cf. de Winterfeld (1899). 
wealthy city of Speyer had educated the eleventh, Tanastus. Hagen excluded himself, so the king took up the twelfth place.

Even though it is difficult to say which element prevails, the epic man-to-man fight or the cataloguing approach (i.e. the enumeration and the miniature-like portraiture), the fact that both classical structures have been fused together is typical for medieval poetics and its attitude toward the classical models.

Catalogues, however, can appear also in a different way. When we return to Aldhelm's De uirginitate, we ought to recognise that the largest part of the work is made up of a catalogue of virgins, both in his prose and in his poetry:

\begin{abstract}
Aldhelm's prose version, De uirginitate 19:66
Sed ne forte propriae disputationis uerbosa garrulitas aut garrula uerbositas firmo scripturarum fulcimento carens a quolibet criminetur, purpureos pudicitiae flores ex sacrorum uoluminum prato decerpens pulcherrimam uirginitatis coronam Christo fauente contexere nitar.
\end{abstract}

But I do not want anyone to incriminate my exposition for prolix garrulity or garrulous prolixity while missing the firm foundation of Scripture. For that reason, I will pick the purple flowers of pudency from the field of the Holy Books and try with Christ's help to make the most beautiful garland of virginity.

Aldhelm's metrical version, De uirginitate 20-2:

20 Sic modo heroica stipulentur carmina laudem,

Ut fasti seriem memini dixisse priorem

Et dudum prompsit uoto spondente libellus!

So, let now heroic poems specify the praise as I remember to have said in a previous list of my book and which my booklet may finally produce in answer to my wish.

In the older prose version Aldhelm speaks of making a wreath from the beautiful flowers he excerpts from his reading, while in the following metrical redaction, his heroic songs praise the virgins whom he remembers to have already mentioned in a solemn series. And indeed, both his poem and his treatise seem to contain nothing more than a very well composed and meditated catalogue of virgins.

This approach might have been at the origin of the very successful poetical evocations of abbots and bishops, listing them chronologically and giving them a short biographical sketch. Alcuin's poem on the bishops of York constituted the first transposition of Aldhelm's still catalogic approach to the emancipation of the list as the means for a more or less independent narrative. Walahfrid's history of the monastic tradition of Reichenau and its abbots retransforms the catalogue into a prologue to his actual narrative. Both Alcuin's and Walahfrid's approach

66 Cf. Ehwald (1919d, 353). 
show that the epic catalogue had become an independent structural element that could be elaborated into an autonomous poem with its own narrative structure or combined with other elements into a more complex narrative unit.

In this sense, we see catalogues appear in poetical miracle collections but also in the epics of the 'new mythology' in the $12^{\text {th }}$ century. ${ }^{67}$ Bernardus Silvestris in his Cosmographia (c. 1147) ${ }^{68}$ and especially Alan of Lille in his De planctu naturae (before 1170) ${ }^{69}$ and his Anticlaudianus (c. 1180) turned the catalogue into a narrative element that by far surpassed the classical structure in its length and importance. The catalogues of plants and animals in Alain de Lille's De planctu naturae might be considered to be extended descriptions, but they become narratives in their own right that transgress the boundaries of their ekphrastic context.

Catalogues thus became a very popular new genre within medieval poetics, merging both the classical epic tradition and the late antique poetics of fragmentation. ${ }^{70}$

\subsection{Dreams}

A comparable development seems to have occurred with dream sequences in medieval Latin epic which combined the nightly apparition of the hero in classical epic with the allegorical dreams of late antique epic and the Christian visionary tradition.

The first, more elaborate poetical visionary dream can be found once again in Carolingian literature. Walahfrid's already mentioned Visio Wettini reworked Heito's prose version into an epic event that takes its departure from a dream vision full of classical references, combined with elements from the Christian mystical tradition (Walahfrid, Visio Wettini 206-10): ${ }^{71}$

Ergo ubi membra suo componit languida lecto,

Conclusis oculis penitus dormire nequibat.

Spiritus ecce doli foribus processit apertis

Clericus in specie, frontis latuere fenestrae,

Ut nec signa quidem parui uideantur ocelli.

So, when he put his tired limbs to rest in his bed and closed his eyes, he could hardly have fallen asleep. Look, a spirit of deception entered through the open door, looking like a cleric.

67 Cf. Schaller (1993, 39).

68 Cf. Dronke (1978).

69 Cf. Häring (1978).

70 Cf. Roberts (1989).

71 Cf. Russell (1988, 42-4). 
The windows of his eyes were hidden by his brows so that no sign could be seen of his tiny eyes.

The first line reappropriates the opening of the dream vision in Lucan. 3.8-9 when his late wife Julia appears to Pompey in a dream vision. It even more resembles the opening of the dream vision in the Culex (206-7) where the shadow of the gnat he killed appears to the shepherd and blames him for his ungratefulness. As Wetti first gets to see a demon who threatens him but will be chased away, the allusion to the parodistic poem that was transmitted under Vergil's name need not be a mere coincidence.

Walahfrid was very well aware of the classical tradition of epic dreams and visions. This becomes clear in his own mock treatment in Carmen 19, De quodam somnio ad Erluinum..$^{72}$ Here the appearance of an eagle is introduced by a truly Vergilian contextualisation (1-6):

\section{Nox erat et magni alternis per climata coeli \\ Ignibus auxerunt astra remota iubar; \\ Pollachar infusum Lethaeo munere somnum \\ Emotis curis, noctis amabat opes. \\ 5 Cum subito tenebras fama est Iouis armiger altas \\ Decutiens, oculis uisus adesse uiri.}

It was night and by the regions of the heavenly space the distant stars brightened their radiance by the flickering fires. Pollachar was infused by the Lethean gift and slept. All sorrows gone, he enjoyed the wealth of the night. Then, suddenly, they say that Jove's esquire tore up the deep darkness and seemed to appear before the eyes of the man.

The high epic style of the opening line is first broken by the second line that does not continue as another heroic verse but as a pentameter, thus creating a distich instead of a continuous heroic narrative. The bizarre and surely parodistic name Pollachar in the third line makes the contrast even more blatant. This fragment demonstrates Walahfrid's profound sensibility and understanding of classical poetics. His linking the vision of the Christian afterworld in his Visio Wettini to the dream visions from classical epic can therefore be considered a conscious choice.

This emancipation of the classical dream vision as an independent topic of a guided visit to the afterworld reached its high point with Dante's Divina Commedia (c. 1308-1320), which the author himself at the closing of the Vita Nuoua addresses as a vision. Moreover, the Divina Commedia opens with Dante awaking from a deep dream (1.11-12): "tant'era pien di sonno in su quel punto / che la verace via abbandonai." Dante thus reconnected with a tradition that in the meantime had

72 Cf. Dümmler (1884c). 
been almost entirely abandoned. One of the last previous examples had been Tnugdali's prose vision, which was written just before 1150 .

Another elaboration of the dream vision had gained ground instead. Epic dream sequences proved an excellent opportunity to develop another reality and as such it became a popular topic in $12^{\text {th }}$ and $13^{\text {th }}$-century poetics. Two famous examples are Alan of Lille's De planctu naturae (before 1170) and the Roman de la rose (1230/1275): they treat the dream as a door that opens into another world, into which the dreamer is introduced. The guide is normally missing, but he may appear as a person within the dream itself. This scheme was applied for the first time in the Metamorphosis Goliae (early 1140s). ${ }^{73}$ The evolution of the dream vision into this completely autonomous form seems somehow to have been connected to the emergence of the roman courtois and its construction of a dreamy otherworld within the text. A late climax of this literary evolution was the Hypnerotomachia Poliphili (around 1500), but this entire later evolution seems to have proceeded out of the visionary dreams of hell and heaven, in which a messenger of the other world enters the life of the protagonist. He brings him a message but then takes him along on a guided tour through the afterworld. The described views of hell and heaven developed the classical, notably Vergilian image of Tartarus and Elysium by mixing them with Jewish and Christian apocalyptic themes and motifs. Two elements from classical epics, the dream vision and the katabasis, were thus combined into an entirely new and independent narrative that conformed to the Christian mindset and that became yet another starting point for new forms of literary expression.

\subsection{Heroic verse}

When looking back on the two elements from classical epics treated here, the catalogue and the dream vision, some indications can be deduced for the relationship of medieval epicity with its classical roots. One of the fundamental ways of treating classical epic structures in the Middle Ages was their deconstruction. Structural elements were detached from their contextual surroundings, often dismembered and revaluated in their functional potentialities. A literary emancipation took place that made them or their components into new and independent narratives and opened them up for experimentation, which took entirely new directions and led to forms of literary expression that remain incomprehensible as long as a scholar's view is focused exclusively on the original structures and their appearance and functioning in classical epics.

73 Cf. Wetherbee (2017). 
This procedure can be further illustrated by the most fundamental element of classical epic, the dactylic hexameter or the heroic verse. As mentioned earlier, the heroic verse remained fundamental to the sense of epicity during the entire Middle Ages. Nonetheless, this does not imply that it was as sacrosanct as it had been during antiquity. Two evolutions have to be singled out that have startled scholars since the birth of classicism and evoked their strongest disapproval. ${ }^{74}$

In a very early stage already, the hexameter was rivalled by the elegiac couplet. Ovid was the first to use the distich for longer narrative texts but it became more common in Late Antiquity (Rutilius) and even almost self-evident in the Carolingian period. Ermoldus Nigellus' poem In honorem Hludowici imperatoris (around 827) in four books and some 2500 lines was completely written in the elegiac mode. ${ }^{75}$ The same remains true for the Ysengrimus, the first animal epic (just before 1150), consisting of almost 6600 lines, divided over seven books. ${ }^{76}$

Reflection upon the tension between the use of the elegiac couplet and the heroic content of the story, however, occurred only in the $13^{\text {th }}$ century. Albert of Stade, poet of the Troilus (before 1250, c. 5300 lines), explains in his hexametrical prologue why he wrote his Homeric story in distiches (Troilus, prologue 6-22): ${ }^{77}$

Res gestae regumque ducumque ferocia facta

Quo scribi possent numero monstrauit Homerus,

Scilicet heroico. dicetur forsitan isti

Currere uersiculi quia deberent pede tali,

10 Quodque per exiguos magnorum magna uirorum

Proelia non deceat elegos scripsisse, probabunt.

Sane concedo, sed gesta miserrima scribo

Et strages miseras miserorum, qui misereri

Noluerant sibi nec aliis sed morte metebant

15 Se misera misere, misero stimulante furore.

Per miseros igitur elegos hoc ducere carmen

Decreui miserum, sortem miseratus eorum

De quibus hic legitur, miseri qui castra sequuntur.

Hac noster ratione stilus non debuit istas

20 Scribere nec debuit heroum carmine mortes,

Sed numeris sub disparibus lex metrica saltat,

Tamquam, de miseris haec est narratio, dicat.

Homer showed in what meter the deeds of kings and the bold achievements of generals can be written, that is in the heroic one. Perhaps it will be argued that these modest lines

74 I have elaborated the problem of classicism in the Middle Ages in Verbaal (2016a).

75 Cf. Dümmler (1884a). See also Faral (1932).

76 Cf. Voigt (1884), Mann (1987), and Mann (2013).

77 Cf. Merzdorf (1875). 
ought to run in the same feet and they will prove that the great battles of great men should not be written by way of mean elegiacs. I agree but I write of pitiful deeds and the pitiful slaughtering of pitiful victims, who did not want pity for themselves or for others but who reaped themselves pitifully in a pitiful death, incited by pitiful rage. That is why I decided to build this pitiful poem by way of piteous elegiacs, as I felt pity for the destiny of those on whom you can read here, when they went miserably to battle. For this reason, our pen could not write these deaths nor was allowed to do so in a poem of heroes, but by unequal meters the metrical law is blown up as if it says: "This story is about piteous men."

The same argument was advanced by John of Garland in De triumphis Ecclesiae (c. 1250). The poet justifies his choice for the elegiac couplet in his prologue with the sad topics he has to treat (De triumphis Ecclesiae, prologue, stanza 14):

Cur et quid scribam tetigi; monstrabitur inde

Forma stili, formae conuenit ordo suus.

Quantum differtur terrae promotio sanctae

Haereticis claudis, carmina clauda docent;

5

Versibus imparibus expirat syncresis, umbra

Effugit, emergit lux, ratioque patet.

Is modus est, elegos parit hic elegia, risum

Proscribit, lacrimas euocat, ora rigat;

Post risum plorat fallacia, ridet amoena

$10 \quad$ Sponsa Dei; queritur ista, sed illa canit.

I touched upon why and what I will write. Now the form of the style will be demonstrated. Its order adapts to the form. The limping poem shows the distance that separates the exaltedness of the Holy Land from the limping heretics. By the unequal verses the comparation is evoked, the shadow flees, light rises and reason becomes cleared. This is the way. Here elegy gives birth to elegiacs, defies laughter, provokes tears, grieves the cheeks. After the laughing, God's Spouse weeps over the deceit and smiles at the delight. She complains over the first, but sings over the last.

This link of the elegiac couplet with sadness had only been restored in the $13^{\text {th }}$ century. Before then, rather the joy of writing in this Ovidian meter seems to have prevailed because it put technical virtuosity more to the test than the hexameter alone. This wish to display technical virtuosity is important to understand the other 'deviation' from classical norms, the Leonine hexameter. Although internal rhymes did occur now and then in classical verse, most often in Ovid's pentameters, it was a rule to avoid them. Carolingian poetry introduced the Leonine hexameter during the second generation, mostly monosyllabic and not generalised. In Latin poetry of the $10^{\text {th }}$ and $11^{\text {th }}$ century it was omnipresent and further developed into a stylistic feature that was not only generalised through entire poems but also uniformised to a disyllabic rhyme. Even more elaborate rhyme schemes were created in this period that have evoked the fiercest judgments of classical scholars. 
The application of the different rhyme schemes betrays, first of all, a wish for technical perfection. ${ }^{78}$ The most refined poet in this sense, Hildebert of Lavardin, distributed different schemes sparsely over his Vita Sanctae Mariae Egiptiacae (before 1107) that can be rightly called a hagiographic epic. ${ }^{79}$ Reginald of Canterbury in his Vita Sancti Malchi (c. 1107) offered a much more exuberant application of all kinds of rhyme schemes. ${ }^{80} \mathrm{~A}$ more balanced approach is taken by the anonymous poet of the Historia Theophili. He was more selective in his application of the different kinds of rhyme and meter, but not as stern as Hildebert (Historia Theophili 9-16):81

Mortuus hinc fletur praesul, conuentus habetur

10 Pro successore, sit eo qui dignus honore.

Complacuit sacer ut meruit uir ad hoc memoratus;

Hic uetuit quod onus metuit graue pontificatus.

Dum petitur, nec is obsequitur, communiter itur:

Eligitur, quia diligitur, meritus quia scitur.

15 Consilium sanum uenit ad metropolitanum,

Qui iubet ut ueniat, quo confirmatio fiat.

They mourn for the bishop's death. A council is held to decide over his successor. Who might be worthy of this honour? The saintly man whom we have mentioned gains the favour, as he deserves it. He refuses because he fears the heavy load of the bishopric. They ask him but he does not give in. All come together. He is chosen, because he is beloved and because he is known to have deserved it. The healthy decision reaches the metropolitan who orders him to come so that he may be consecrated.

The story itself is told in Leonine hexameters, but where the tension increases, the poet changes to the more complex, more rhythmical, and more ominous sound of the tripartiti caudati and the trinini salientes with their threatening drone. This happens in the fragment above when Theophilus is elected to succeed to the bishopric but refuses (Historia Theophili 11-14). After these four verses of increased suspense the story returns to the calmer rhythm of the disyllabic Leonine until the next episode of suspense.

All these poems stem from the late $11^{\text {th }}$ or early $12^{\text {th }}$ century. Soon, this kind of rhyming hexameters were sternly rebuked by school masters and even by those poets who had been the leading figures in their elaboration, like Marbod of Rennes who condemns them in his later poems. It shows, however, that even the heroic verse itself was not safe. What happened here does not differ from what we saw

78 Cf. Meyer (1905).

79 Cf. Larsen (2004).

80 Cf. Lind (1942).

81 Cf. Migne (1854). 
before with the other structures of classical epic. The heroic verse was isolated as a unit, and dismembered, or deconstructed in its structural elements. Next, out of these elements particular aspects were developed into almost independent building blocks of epicity that give birth to another way of constructing (and reading) the verse.

Medieval poetics in its attitude towards classical epicity appears to be one of deconstruction and emancipation: deconstruction of epic material into its structural elements and emancipation of these elements from their classical context in order to become the constructive material for an entirely new epicity, that of medieval Latin.

\section{Constructing medieval Latin epicity}

Deconstructing classical epic structures in order to reconstruct them into independent and new narrative elements consists of two processes: 1) isolating the individual structural elements in independent units, 2) recomposing them according to the exigencies of the new poetics. It is this second process that offers the most valuable information on the structural factors that make up medieval poetics and, in our case, medieval epicity. For that reason, after having demonstrated how classical epic structures survived in a decomposed way in medieval Latin poems, I will conclude my analysis by turning to their recomposition into a new form of epicity and to the underlying compositional principles.

\subsection{Truth}

It has already been noticed that one of the fundamental continuities throughout medieval Latin literature was a general obsession with the truth. Some poets even went so far as to decline the title 'poet' for their versification of historical events, as did an anonymous author in his poem De excidio Troiae (around 1150). ${ }^{82}$ For him, 'poet' refers to the classical authors because they mix truth with fiction whereas a modern and Christian uersificator ought to keep to the truth.

Truth, however, can be strived for on different levels and in different ways. One way of course is to avoid mendacity and thus to eliminate all references to fabulous or non-historical embellishments. The first epic element to be eliminated was the divine machinery. This was not limited to pagan gods, but also included

82 Cf. Stohlmann (1968). 
angels, devils, and divine intervention. The only exception was the vision of the afterworld, where the evoked reality itself transcends the human sphere. Otherwise, superhuman influences is enacted in an indirect way and almost always through human intermediation.

A nice example is offered by Hrotsvitha in her Gesta Ottonis (completed after 965), in which Otto's divine destination is confirmed by his being rescued out of an impossible situation. Brought into serious troubles during the Battle of Andernach (939), Otto starts weeping, like another David, and praying for the loss of so many innocent souls. He immediately receives divine mercy in the form of his own army suddenly breaking forth and putting the enemy to rout (Gesta Ottonis 266-79):
At si forte suos, pugna crescente sinistra,
Audiuit socios letali uulnere laesos,
Praedicti regis lacrimans mox utitur orsis, Quae maerens dixit, tristi cum pectore sensit
270 Icitibus angelici populum gladii periturum:
'En, qui peccaui, dixit, facinusque peregi;
Hinc ego uindictae dignus sum denique tantae!
Hi quid fecerunt, damnum qui tale tulerunt?
Iam nunc, Christe, tuis parcens miserere redemptis,
275 Ne premat insontes iusto plus uis inimica!'
Has igitur preculas miserans diuina potestas
Parcebat regis solita pietate ministris,
Et dedit optatum miserans ex hoste triumphum, Iusto praedictos comites examine perdens.

But when the king, with the hateful battle coming to a head, by chance heard that his friends were fatally wounded, he spoke under tears the words which the other one spoke in pain, as his sad heart felt how the people were dying under the strokes of the angel's sword. He said: "Look, it is me who sinned. I committed the crime. On me thus such great revenge must fall! Those men, what did they do to deserve such a penalty? Christ, save them now and take pity on those that you have redeemed! Let no hostile force suppress their innocence more than is just!” The divine power felt compassion for these little prayers and saved the king's servants with its usual benignity. Out of compassion, it gave the desired victory over the enemy and by a righteous selection brought down the mentioned counts.

For several reasons, Hrotsvitha offers an important example of the medieval poetic or epic mindset. As already mentioned, the Italian editor and translator refused to call her poem on Otto an epic. They preferred to label it a historical verse panegyric ("un poemetto storico-panegiristico") 83 because it misses all the essential, genredefining elements that constitute an epic poem. These structures are enumerated as follows: catalogues, arming scenes, embassies, banquets or hunting scenes,

83 Robertini/Giovini (2004, 258). 
lyrical intermezzi, digressions and descriptions, Homeric similitudines. For some of these classical elements, we already discussed what happened to them in medieval poetics. Even though she was writing almost two centuries before Matthew of Vendôme, Hrotsvitha's poetics conformed in many aspects to the lines set out in the Ars uersificatoria. She stuck to her plan and did not allow herself any deviations that would have encroached on the truthfulness of her story.

But apparently the editor did not consider Hrotsvitha's own words either. Just before her account of the battle Hrotsvitha allows her own voice as a poetess to interrupt the storyline and to explain her poetical responsibilities (Gesta Ottonis 243-9):

Sed nec hoc fragilis fas esse reor mulieris

Inter coenobii positae secreta quieti,

245 Ut bellum dictet, quod nec cognoscere debet.

Haec perfectorum sunt conseruanda uirorum

Sudori, quis posse dedit sapientia patris

Omnia compositis sapienter dicere uerbis

Principium qui cunctarum, finis quoque rerum.

But I do not think it is permitted to a fragile woman who is placed in the isolation of a quiet monastery to sing of war which she ought not even know about. Such themes should be the prerogatives of perfect men to sweat over, who have the capacity to say everything in wisely composed words, thanks to the wisdom of the Father, of Him who is the beginning and the end of all things.

As a woman and, even more, as a nun living in the quiet of the monastery, Hrotsvitha does not feel authorised to speak about wars and events about which she is not even allowed to know. In other words, it would make her a liar, and truthfulness was the main objective of her poem about Otto. In two of the three prologues to the poem, Hrotsvitha deplores the absence of written sources that would have guaranteed the truthfulness of what she wants to say.

Hrotsvitha, Gesta Ottonis, Praefatio ad Gerbergam 4:

In huius sudore progressionis quantum meae inscitiae obstiterit difficultatis, ipsa conicere potestis, quia haec eadem nec prius scripta repperi, nec ab aliquo digestim suffienterque dicta elicere quiui.

How difficult it has been for my ignorance to progress in this laborious project, you can judge for yourself. I did not find anything that had been written on these events before. Neither was there anyone who was able to tell them to me in an orderly and sufficient way. 
Hrotsvitha, Gesta Ottonis, Prologus I ad Ottonem 14-23:

Sed non exemplum quisquam mihi praebuit horum,

15 Nec scribenda prius scripti docuere libelli;

Causa sed est operis tantum deuotio mentis,

Haec et ad audendum suadebat opus metuendum.

Nam sat formido quod gesta tui modulando

Incaute sim falsa sequens, non uera retexens:

20 Sed non hoc suasit mala mis praesumptio mentis,

Nec summa ueri contempta sponte fefelli;

Sed res, ut scripsi, sese sic prorsus habere,

Ipsi dicebant, mihi qui scribenda ferebant.

But nobody gave me a model for this nor did books that had been previously written teach me what to write. The reason behind the work is only the devotion of my mind. This persuaded me to dare and undertake this frightening work. For, I am afraid that by singing your deeds I will unwillingly follow what is untrue, not being able to uncover the truth. Yet, this is not suggested to me by some ill-advised presumption of my mind, neither did I fail by voluntarily despising the essence of truth. Everything I describe happened that way. That is what I was told by those who ordered me to write it all down.

To Hrotsvitha, written sources would have guaranteed the truthfulness of her own poem. This touches upon one of the most crucial criticisms as regards medieval (and Christian) epicity: many of them were considered to be 'just' paraphrases of prose texts. Now, it will be clear that to the medieval mindset and its aspirations for truthfulness the close interdependency between poetry and prose sources belonged to the fundamental aspects of its poetics. The main function of epic was less considered to be the demonstration of the author's personal poetical skills than the praise of the poem's protagonist. A true panegyric, however, had to cling to veracity and thus to the historical truth, which could be deduced from historiographical sources and to these was reckoned much more than the modern mind would admit. Even the origins of the Waltharius in German heroic songs belonged to them. Paraphrase thus cannot be considered an exclusive criterion for medieval epicity; it is rather the condition that guarantees the epic's pursuit of truthfulness.

\subsection{Veracity}

Epicity had yet another value within medieval poetics: truthfulness according to medieval poetics was not just the denial of mendacity but, due to its close link to historical sources, it also demanded veracity. The poet thus tried to comply with the natural expectations of his readership to the highest degree. This implies, first of all, the preference of the natural above the artificial order. Chronology became 
a fundamental feature to establish veracity. For that reason, masters of poetics like Matthew of Vendôme stressed the necessity of proceeding in a natural and gradual way (Ars uersificatoria 4.13):

Hucusque dictum est quomodo superflua debent resecari, sequitur quomodo minus dicta debeant suppleri. Verbi gratia, in humanis actionibus quedam est ordinaria successio: quedam enim actiones aliarum sunt preambule, quedam aliarum sunt consecutiue: uerbi gratia, in actuali amoris exercitio precedit intuitus, sequitur concupiscentia, accessus, colloquium, blandimentum, ad ultimum uotiua duorum congressio; teste enim Ouidio

Vix caret effectu quod uoluere duo (Ov. am. 2.3.16).

Istos autem gradus accionis testatur Ouidius dicens:

Per numeros ueniunt ista gradusque suos (Ov. ars 1.482).

Similiter in exsecutione materie actionum gradus expresso debemus imitari uestigio, ut narrationis nulla sit intercisio sicut nec actionum. Predictarum siquidem actionum ordinem intercidere uel sincopare uidetur Ouidius, ubi loquitur de Ynachide dicens:

Viderat a patrio redeuntem Iupiter Io

Flumine, et ' $O$ uirgo Ioue digna tuoque beatum

Nescio quem factura thoro, ...' (Ov. met. 1.588-90)

etenim huius narrationis contextus interciditur, pretermittuntur enim duo gradus, scilicet concupiscentia et accessus, intuitus autem et colloquium continuantur tamquam ordinariam habeant successionem. Sed Ouidius, ut in fine suo operis testatur:

Emendaturus, si licuisset eram (Ov. trist. 1.7.40).

Thus far we explained how to cut down what is superfluous. This is now followed by instructions on how to complete what remains a bit meagre. For example, all human actions know a kind of normal order of succession. Some actions must inevitably precede others, some must necessarily follow. For example, in the actual practice of love, first comes seeing, then follow attraction, approach, addressing, caressing, and finally the wish of both to lay together. As Ovid testifies:

What two desire will hardly miss its results (Ov. am. 2.316).

Ovid gives witness of these different steps in an action when he says:

These things come in their own measures and steps (Ov. ars 1.482).

Similarly, in the elaboration of our material we have to follow the steps in the actions by way of the traces we describe in order to avoid any interruption in the narration as well as in the 
actions. Nonetheless, Ovid seems to interrupt or to abbreviate the order of the actions just described when he talks of Io.

Jove saw Io as she returned from her father, the river, and:

"O maiden worthy of Jove that will make happy whoever it is

in your bed ...” (Ov. met. 1.588-90).

Here, the order of the story is interrupted, because two steps are left out: attraction and approach. The address follows immediately on the sight as if this were the ordinary succession. But at the end of his work, Ovid himself admits:

I would have emended it if I could (Ov. trist. 1.7.40).

A similar approach implies attention for the successive phases of a process with the obligation not to leave out any of the essential steps. Moreover, as a poet, you are not allowed to change the natural order. In the commentary to the first six books of the Aeneid, ascribed to Bernardus Silvestris (c. 1130?), ${ }^{84}$ the author elaborates on the apparent tension between the artificial order of the epic and the high esteem Vergil, as the supreme poet, enjoyed (Commentum super sex libros Eneidos Virgilii, prologue):

Notandum est in hoc libro geminum esse narrationis ordinem, naturalem scilicet et artificialem. Naturalis est quando narratio secundum seriem rerum ac temporum distribuitur, quod fit dum eo ordine quo res gesta est narratur dumque quid tempore primo quid consequente quid ultimo gestum sit distinguitur. Hunc ordinem Lucanus sequitur. Artificialis ordo uero est quando a medio narrationem incipimus artificio atque modo ad principium recurrimus. Hoc ordine scribit Terentius atque in hoc opere Virgilius. ... Nunc uero hec eadem circa philosophicam ueritatem uideamus. Scribit ergo in quantum est philosophus humane uite naturam. Modus agenda talis est: in integumento describit quid agat uel quid paciatur humanus spiritus in humano corpore temporaliter positus. Atque in hoc describendo naturali utitur ordine atque ita utrumque ordinem narrationis obseruant, artificialem poeta, naturalem philosophus.

We must note that the narration of this book has a double order, both natural and artificial. The natural order is applied when the narration is composed according to the chronological sequel of events. This means that the story follows the order in which things happen and a distinction is made between what happens first, what follows, and what happens last. This is the order Lucan follows. The artificial order is applied when we start by artifice the narration from the middle and then later return to its beginning. This is the order in which Terence writes and also Vergil in this work. ... Let us now have a look at these same topics according to their philosophical truth. As a philosopher, Vergil writes on the nature of human life. The way we have to deal with it is as follows. In this 'cover'85 he describes what the human spirit should do or what it should suffer for the time it is positioned in the human body. For this

84 Cf. Basile (2008) and Wetherbee (2015).

85 For the definition and meaning of the term integumentum, see below. 
description, he uses the natural order and as such he keeps to both forms of order: as a poet to the artificial one, as a philosopher to the natural one.

Vergil's epic thus has an artificial order that wants to retain the reader's attention, but underneath a natural order is hidden, and the commentator takes upon himself the task to uncover it. This brings us immediately to another fundamental aspect of the medieval mindset. Real truth is always of a spiritual nature. Visible reality, first of all, has to be decoded and interpreted as a sign that refers to the actual transcendent truth, and no text can be truthful if, in the end, it does not refer to this absolute truth.

The most explicit elaboration is provided in Hrabanus Maurus' De uniuerso or De rerum natura (around 845), a mystical encyclopaedia on the worldly appearances, as they can be found in the Sacred Scripture, the Church Fathers, and the classical tradition. ${ }^{86}$ Hrabanus builds on Isidore's Etymologiae, but he adds a mystical sense, or rather senses, to everything, as nothing refers only to one unique meaning. Just as words tend to be ambiguous, so are things due to their double nature: material and spiritual as willed by God. Their meaning is not only potentially polyvalent, but it can even be contradictory (Hrabanus Maurus, $D e$ uniuerso, Praefatio ad Hemmonem):

Haec enim omnia mihi sollicite tractanti uenit in mentem ut iuxta morem antiquorum qui de rerum naturis et nominum atque uerborum etymologiis plura conscripsere, ipse tibi aliquod opusculum conderem in quo haberes scriptum non solum de rerum naturis et uerborum proprietatibus, sed etiam de mystica earumdem rerum significatione ut continuatim positam inuenires historicam et mysticam singularum expositionem.

This all comes to my mind when thinking it all over. For, according to the customs of the ancients who dedicated much of their writings to the nature of things and the etymology of names and words, I want to dedicate a small work to you that offers not only what characterises the nature of things and words, but also their mystical significance. Then, you will find together both the truth of each and its mystical explanation.

A similar work was undertaken by Alan of Lille in his Liber distinctionum (after 1150). ${ }^{87}$ In spite of its much more scholastic nature, the underlying vision remains the same (Liber distinctionum, Prologus alter):

Et ideo ne falsum pro uero affirmet theologus, ne ex falsa interpretatione errorem confirmet haereticus, ut a litterali intelligentia arceatur Judaeus, ne suum intellectum sacrae Scripturae ingerat superbus, dignum duximus theologicorum uerborum significationes distinguere, metaphorarum rationes assignare, occultas troporum positiones in lucem reducere, ut liberior ad

86 Cf. Migne (1852).

87 Cf. Migne (1855). 
sacram paginam pandatur introitus, ne ab aliena positione fallatur theologus, et sit facilior uia intelligendi; minus intelligentes inuitet, torpentes excitet, peritiores delectet; et sic diuersae uocabulorum acceptiones, quae in diuersis sacrae paginae locis jacent incognitae, in lucem manifestationis reducantur praesentis opusculi explanatione.

We have to avoid both that a theologian judges the false for the truth and that a heretic by way of a false interpretation imposes his errors. Besides, the Jews have to be shut off from the literal understanding to prevent them from imposing their haughty understanding on Sacred Scripture. For that reason, we thought it worthwhile to distinguish between the significances of theological terms, to assign reasons to the metaphors, to throw light upon the hidden propositions of the tropes. Then, the access to the Sacred Page will open itself more freely as the theologian will not be deceived by alien propositions and the way to understanding will be easier. It may invite those who understand less, incite those who are numb, and delight those who are experienced. The divergent understandings of the words, as they lay unknown in different places of the Sacred Page, will be brought into clear light by the explanations that can be found in the present work.

Even when this multifold reading applies in the first place to Sacred Scripture, it had become such an integral part of the medieval mindset that its application has been expanded widely beyond the field of theology and biblical studies. In the letter to Cangrande, attributed to Dante, a threefold reading of his Divina Commedia is proposed, and Bernardus Silvestris' uncovering of the philosophical meaning in Vergil's Aeneid has to be looked at from the same perspective.

The most obvious illustration is offered by hagiography. Both in prose and in poetry the hypotext of the Bible offers the ultimate scheme to which the story, the narrative, and the hero have to conform. Every saintly biography is formed on the scheme, as it is offered to the poet in Christ's life or in that of the biblical heroes. In hagiography this prevails both in prose and in poetry, but, as we saw in the Gesta Ottonis, it also applies to historical epicity. As the true hero in Christian terms is not the great warrior but the saint, even the war and chivalric heroes will often be formed according to this spiritual truth. Hrotsvitha's image of a passive and praying Otto is just one example. He is portrayed as another David, whose life and character premodel or prefigurate Otto's.

As each heroic life thus ought to be a kind of reformulation of Sacred Scripture, it becomes more or less the task of the poet to uncover this spiritual truth. This is what Bernardus Silvestris promises to do in his comment on the first six books of the Aeneid (Commentum super sex libros Eneidos Virgilii, prologue): 88

Integumentum est genus demonstrationis sub fabulosa narratione ueritatis inuoluens intellectum, unde etiam dicitur inuolucrum ... Ordo deinceps talis est ut singolorum uoluminum duodecim integumenta secundum ordinem aperiamus.

88 Cf. Jones/Jones (1977). 
A 'cover' is a kind of demonstration, in which the understanding is veiled in a fictitious story. That is why it is also called a 'veil' ... The order [of this book] is such that we will open the covering of each of the twelve books according to the order in which they appear.

Another way was to retell the story. Rephrasing history thus became a means to show the truth hidden in the deeds and in the lives of those one wanted to exalt. Paraphrases, once again, should not be taken as a denial of the epicity of a work, but rather, according to medieval poetics, as the clues to disclose the 'epic' character of a text that limits itself to an account of the littera or the historia of just the temporal truth. 'Epic' then has to be considered the highest form of history writing.

\subsection{Laughing}

Finally, one other aspect of medieval epicity has to be brought to the fore, the humoristic elements. Classical poetics knows a strict separation between the different styles and does not allow them to mix: classical epicity is written in the high register and has to respect it. Of course, this does not exclude parody or irony with Ovid as the great master, but a roaring outburst of laughter is considered inappropriate to the epic genre and remains banished from it.

Not so in medieval epicity. Hardly any medieval epic lacks a sense of humour, often in a rather burlesque way or in unexpected situations. In the Old French cycle of Guillaume d'Orange (for the greatest part dating from the $12^{\text {th }}$ century), the hero breaks into laughter almost every time when he gets in trouble. In the heat of the Battle for Paris Abbo describes in his epic account (before 900) how the besieged started to insult and mock the assailants (De bello Parisiacae urbis 1.99-110): ${ }^{89}$

Qui uero cupiunt murum succidere musclis,

Addit eis oleum ceramque picemque ministrans, Mixta simul liquefacta foco feruentia ualde, Que danis ceruice comas uruntque trahuntque; Occiduunt autem quosdam, quosdamque suadent Amnis adire uada. Hoc una nostri resonabant:

105 'Ambusti sequane ad pelagos concurrite, uobis Quo reparent alias reddendo iubasque mage comptas.' Fortis Odo innumeros tutudit. Sed quis fuit alter? Alter Ebolus huic socius fuit equiperansque

89 Cf. Waquet (1942). 
Septenos una potuit terebrare sagitta,

Quos ludens alios iussit praebere quoquinae.

Some want to attack the wall with picks. [Odo] throws oil on them, mixed with wax and pitch. This mixture was made fluid in the oven and glowing with fire. It burns the hairs of the Danes and tears their heads apart. Some of them were killed. Some of them hurried to the river. One of our men shouted after them: "Burnt as you are, hurry to the waters of the Seine that they may restore them to you and send you back with your hairs better combed.” The strong Odo slayed countless enemies. But who was the other hero? Ebolus was his companion and his equal. With one arrow he could kill seven enemies and, jesting, ordered the others to bring them to the kitchen.

A similar rather raw humour can be encountered in the Waltharius. During the final battle between Walther, Gunther, and Hagen each of the combatants gets more than severely wounded. Walther amputates Gunther's leg, after which Hagen cuts of his right hand; but with his left hand, Walther manages to chop off about half of Hagen's face. A bizarre scene follows, not exempt from a harsh kind of humour (Waltharius, 1401-24): ${ }^{90}$

Postquam finis adest, insignia quemque notabant:

Illic Guntharii regis pes, palma iacebat

Waltharii nec non tremulus Haganonis ocellus.

Sic sic armillas partiti sunt Auarenses!

1405 Consedere duo, nam tertius ille iacebat,

Sanguinis undantem tergentes floribus amnem.

Haec inter timidam reuocat clamore puellam

Alpharides, ueniens quae saucia quaeque ligauit.

His ita compositis sponsus praecepit eidem:

1410 'Iam misceto merum Haganoni et porrige primum;

Est athleta bonus, fidei si iura reseruet.

Tum praebeto mihi, reliquis qui plus toleraui.

Postremum uolo Guntharius bibat, utpote segnis

Inter magnanimum qui paruit arma uirorum

1415 Et qui Martis opus tepide atque eneruiter egit.'

Obsequitur cunctis Heririci filia uerbis.

Francus at oblato licet arens pectore uino

'Defer' ait 'prius Alpharidi sponso ac seniori, Virgo, tuo, quoniam, fateor, me fortior ille

1420 Nec solum me, sed cunctos supereminet armis.'

Hic tandem Hagano spinosus et ipse Aquitanus

Mentibus inuicti, licet omni corpore lassi,

90 It may be said that the Waltharius displays a broad spectrum of affectivities. In the scene (Waltharius 846-77) where Hagen tries to dissuade his nephew from fighting Walther (Waltharius 846-77), the epic acquires a tragic tone that is close to that of the Hildebrandslied. 
Post uarios pugnae strepitus ictusque tremendos

Inter pocula scurrili certamine ludunt.

As all was over, each of them had his trophy. There, on the ground, lay the foot of King Gunther, the hand of Walther and the still winking eye of Hagen. That is the way they had divided among them the treasures of the Huns! Two of them sat down, as the third was already lying on the ground. They wiped off with flowers the blood that covered them. While occupied with these, the son of Alpher loudly called for the timid girl that she may come forth and take care of each of their wounds. As she had obeyed, her fiancé ordered her: "Now, mix the wine for Hagen and offer it to him first. He is a good fighter. Had he just kept the alleged loyalty! Then give it to me, who has suffered more than the others. I want Gunther to be the last one to drink, as he has proven himself to be the most sluggish in the fighting of magnanimous men and he has done the work of Mars half-heartedly and weakly.” The daughter of Heririch carried out everything he said. But as she offered the wine to Hagen, the Frank refused, although he was dry as dust: "Give it first to the son of Alpher, your groom, and lord, girl. For I confess that he is stronger than I am, and, in fighting, he surpasses not only me but everyone." Finally, neither of them mentally defeated, even though tired in all of their limbs, after all the clashing and horrible blows of the combat, Hagen, the Thorn, and Walther of Aquitaine poked fun at each other, drinking the wine and jesting playfully.

The humour can be much subtler, as we noticed in Walahfrid's Visio Wettini, where the appearance of the demons is associated with the appearance of the gnat in the Culex. A comparable subtlety can be detected at the opening of the Alexandreis when the hot-tempered youngster Alexander is addressed by his master Aristotle. The philosopher is depicted as an otherworldly student (Alexandreis 1.59-71):

Forte macer pallens incompto crine magister

(nec facies studio male respondebat) apertis

exierat thalamis ubi nuper corpore toto

perfecto logyces pugiles armarat elencos.

o quam difficile est studium non prodere uultu!

Liuida nocturnam sapiebant ora lucernam,

seque maritabat tenui discrimine pellis

ossibus in uultu, partesque effusa per omnes

articulos manuum macies ieiuna premebat.

Nulla repellebat a pelle parentesis ossa.

Nam uehemens studii macie labor afficit artus

70

et molem carnis, et quod cibus educat extra

interior sibi sumit homo fomenta laboris.

By chance, his master came out of the open room: haggard, pale, unkempt. You saw how much he was dedicated to his study. He had only just left behind his boxing gloves, the logical refutations by which he had exercised his whole body. 0 , how difficult it is not to betray your studies by your appearance! His grey complexion grew wiser by the nocturnal lamplight and the skin of his face seemed to adhere too intimately to his bones. A barren diet infiltrated all parts of his body and weighed down on his fingers and hands. Nothing could be felt between 
the bones and his skin. For, the strenuous efforts of study consumed both limbs and the flesh in lankness. Whatever food the man consumed, was digested by the inner fire of his strain.

Humour can become the overarching trait, like in the animal epics. Perhaps none of the new poetical forms can better illustrate the joy in experimentation that characterises so much of medieval literature. Many poems have been brought into contact with animal epic, but three of them stand out, all three anonymous: the Ecbasis captiui (c. 1050), ${ }^{91}$ the Ysengrimus (just before 1150), and the Asinarius (c. 1200). ${ }^{92}$ Actually, they have little in common, the last one is not even located in an animal world and somehow ranges between the ancient fable and the modern fairy-tale. What they do share is the smile they want to conjure up on the face of their readers. Besides the amusing stories, however, their tactics are completely different. The Asinarius plays with subtle intertextual jokes and the Ecbasis with soft moralistic allusions. The Ysengrimus, by contrast, displays the harshest and strangest humour of the entire Middle Ages, and can be undoubtedly considered one of the most disturbing texts ever written.

What these poems also share is their epicity. They have been characterised as mock epics, but none of them just wants to parody, like their classical predecessors, the Batrachomyomachia or the Culex. They are true epics in their own right, conforming to all the characteristics we assigned to medieval epicity. Their truthfulness is less in the storyline, which is set out to amuse (Bernardus Silvestris' delectatio) than in the underlying message the reader is expected to liberate from its integumentum. In the Asinarius this truth is linked to a knightly and courtly background, to the Trojan tradition, and to the mystery of incarnation. ${ }^{93}$ The Ecbasis captiui refers to an entirely monastic background, depicting the flight of a monk into the secular world, the dangers he faces, and his safe return.

The Ysengrimus is more difficult to categorise. The laugh it provokes is both exuberant and bitter, and its criticism both stinging and hilarious. The truth, as far as it can be grasped, seems to be founded upon the blackest pessimism and upon cheerful mockery. Yet, what makes the poem important for medieval epicity is the fact that it is also the medieval poem which more than any other retakes and reworks classical epic structures. It starts in medias res and contains a long story within the story, told at a banquet. It has a highly complicated structure, based upon the week (seven books), the months (twelve episodes, and the number of books in the Aeneid of course), the number of the apocalyptic beast (almost 6600 lines). The frame tale is enacted within the span of one year. The characters all are

91 Cf. Strecker (1935) and Trillitzsch (1963).

92 Cf. Langosch (1956).

93 Cf. Praet (2013) and Praet (forthcoming). 
accomplished speakers, making the poem a rhetorical masterpiece. There are also epic catalogues, albeit not of warriors, but of animals. The poem does not have any battle scenes, but the entire epic is one long war between the fox and the wolf, ending with the latter's death. ${ }^{94}$

When taking into consideration that the poem seems to make the schools its main target, this classicising aspect of the Ysengrimus can hardly be seen as an innocent choice. It rather suggests that the classical mode is an integral part of the entire satirical or even sarcastic scheme. Obeying that strongly to classical epic standards in a poem of which the content cannot be further remote from the classics, may unquestionably be seen as the ultimate deconstruction of classical epicity. For medieval epicity, the Ysengrimus constitutes somehow the point of no return. It demarcates the line that separates a literary period that still was looking toward classical standards from a literary period that liberated itself completely. What followed was new: allegorical, vernacular. Even though treating traditional or classical subjects, it happened in a different way. Neither the Alexandreis, nor the Troilus, or the Philippis are classical epics. In the end, they were even taken over by prose.

\section{Conclusion}

This contribution to the compendium on classical epic structures and their survival wanted to shed light on and add new impulses to the discussion about the treatment of classical epic in medieval poetics. The discussion took its point of departure from the depreciation medieval epicity encounters in classical scholarship. I tried to demonstrate that the absence of classical epic material is not due to ignorance, but rather a deconstruction of classical epic in order to reconstruct from the resulting elements an entirely new poetry. Medieval epicity proves to be, in my opinion, not a sterile literary field, but rather one of the most experimental poetics that European literary history has known.

Can the poems that result from this experimental poetics still be viewed as epics? The answer depends largely on the point of view the scholar takes. If epicity can only be defined according to the standards of classical Greek and Latin, then surely one may question the epic character of the medieval poems we have discussed in this contribution. But, in that case we may also question the epic character of poems that preceded the classical epics that have become normative, for example, Gilgamesh or the Mahabharata. And what about the vernacular 'epics' of

94 Cf. Verbaal (2004) and Verbaal (2016b). 
Europe? Beowulf, the Nibelungenlied, or the Chanson de Roland: even though they were surely influenced by the classical heritage, they do not conform at all to the classical epic norms and standards. They are more connected with the medieval epicity that preceded and surrounded them, and that gave them their form and even their raison d'être.

In sum, a classicist view is not the best way of understanding medieval epicity. The classical epics certainly survived and lived on in medieval Latin literature, but not as monolithic entities. They were remodelled and recreated, and gave birth to new forms that proved just as vital and vigorous. After all, this is what makes them 'the classics' they are.

\section{Bibliography}

\section{Primary literature}

Agostinelli, E./Coleman, W. (eds., 2015). Giovanni Boccaccio. Teseida delle Nozze d'Emilia. Florence.

Assmann, E. (ed., 1987). Gunther der Dichter. Ligurinus. Hanover.

Basile, B. (ed., 2008). Bernardo Silvestre [Bernardus Silvestris]. Commento all'Eneide. Libri I-VI. Rome.

Bossuat, R. (ed., 1955). Alain de Lille [Alanus ab Insulis]. Anticlaudianus. Texte critique avec une introduction et des tables. Paris.

Canali, L. (ed., 2011). Aquilino Giovenco [Juvencus]. Il Poema dei Vangeli. Milan.

Chiurco, C. (ed., 2004). Alano di Lilla [Alanus ab Insulis]. Viaggio della sagezza. Milan.

Colker, M. (ed., 1978). Galteri de Castellione [Walter of Châtillon]. Alexandreis. Padua/Burgos.

Cremascoli, G. (1995). Henricus Abrincensis [Henry of Avranches]. Legenda Sancti Francisci uersificata, in: E. Menestò et al. (eds.), Fontes Franciscani. Assisi: 1131-242.

De Winterfeld, P. (1899). Gesta Berengarii imperatoris, in: K. Strecker (ed.), Poetae Latini Aeui Carolini, vol. IV.I. Berlin: 354-401.

De Winterfeld, P. (1902). Hrotsvitha of Gandersheim. Gesta Ottonis, in: P. de Winterfeld (ed.), Hrotsvithae Opera. Berlin: 201-28.

Delaborde, H.-F. (ed., 1885). Cuure de Rigord et de Guillaume le Breton. Historiens de PhilippeAuguste, Tome 2: Philippide de Guillaume le Breton [William the Breton]. Paris.

Dronke, P. (ed., 1978). Bernardus Silvestris. Cosmographia. Leiden.

Dümmler, E. (1881a). Alcuini carmina [Alcuin of York]. Versus de patribus regibus et sanctis Euboricensis Ecclesiae, in: E. Dümmler (ed.), Poetae Latini Aeui Carolini, vol. I. Berlin: 169206.

Dümmler, E. (1881b). Angilberti carmina dubia [Angilbert/Engelbert]. Karolus Magnus et Leo Papa, in: E. Dümmler (ed.), Poetae Latini Aeui Carolini, vol. I. Berlin: 366-79.

Dümmler, E. (1884a). Ermoldi Nigelli carmina [Ermoldus Nigellus]. In honorem Hludowici Christianissimi Caesaris Augusti Ermoldi Nigelli exulis elegiaci carminis. Liber I-IV, in: E. Dümmler (ed.), Poetae Latini Aevi Carolini, vol. II. Berlin: 5-79. 
Dümmler, E. (1884c). Walahfridi Strabi carmina [Walahfrid Strabo]. Carmen 19. De quodam somnio ad Erluinum, in: E. Dümmler (ed.), Poetae Latini Aevi Carolini, vol. II. Berlin: 364-5.

Dümmler, E. (1884d). Walahfridi Strabi carmina [Walahfrid Strabo]. Carmen 3. Visio Wettini Walahfridi, in: E. Dümmler (ed.), Poetae Latini Aevi Carolini, vol. II. Berlin: 301-33.

Ehwald, R. (1919b). Aldhelmus [Aldhelm of Malmesbury]. De metris et enigmatibus ac pedum regulis, in: R. Ehwald (ed.), Aldhelmi Opera. Berlin: 59-204.

Ehwald, R. (1919c). Aldhelmus [Aldhelm of Malmesbury]. De Virginitate. I. Carmen, in: R. Ehwald (ed.), Aldhelmi Opera. Berlin: 350-471.

Ehwald, R. (1919d). Aldhelmus [Aldhelm of Malmesbury]. De Virginitate. Il. Prosa, in: R. Ehwald (ed.), Aldhelmi Opera. Berlin: 226-323.

Ellis, E. (ed., 2007). Petrarch's Africa I-IV: a translation and commentary. Diss. Baylor.

Faral, E. (ed., 1932). Ermold le Noir [Ermoldus Nigellus]. Poème sur Louis le Pieux et Epîtres au roi Pépin. Paris.

Festa, N. (ed., 1926). Francesco Petrarca [Petrarch]. L'Africa. Florence.

Fiorese, F. (ed., 2005). Rolandino [Rolandino di Balaiardo]. Vita e morte di Ezzelino da Romano (Cronaca). Milan.

Gardner, J. (ed., 2009). Marco Girolamo Vida [Marcus Hieronymus]. Christiad. Cambridge, MA.

Gompf, L. (ed., 1970). Joseph Iscanus [Joseph of Exeter]. Werke und Briefe. Leiden/Cologne.

Griffin, N. E. (ed., 1936). Guido delle Colonne. Historia destructionis Troiae. Cambridge, MA.

Häring, N. (1978). Alan of Lille, De planctu naturae, Studi medievali 19: 797-879.

Howlett, R. (1885). Stephen of Rouen. Draco Normannicus, in: R. Howlett (ed.), Chronicles of the reigns of Stephen, Henry II, and Richard I, vol. II. London: 589-786.

Huemer, J. (ed., 1891). [Juvencus]. Gai Vetti Aquilini luvenci Euangeliorum libri quattuor. Vienna.

Jaager, W. (ed., 1935). [Beda Venerabilis]. Bedas metrische Vita Sancti Cuthberti. Leipzig.

Jones, J. W./Jones, E. F. (eds., 1977). Bernardus Silvestris. Commentum super sex libros Eneidos Virgilii. The commentary on the first six books of the Aeneid of Vergil commonly attributed to Bernardus Silvestris. Lincoln, NE.

Könsgen, E. (ed., 1990). Hugo von Mâcon [Hugo Matisconensis]. Gesta militum. Leiden/New York.

Langosch, K. (1956). Der Eselprinz (Asinarius), in: K. Langosch (ed.), Waltharius. Ruodlieb. Märchenepen. Basel: 333-57.

Larsen, N. (ed., 2004). Hildebert of Lavardin. Vita beatae Mariae Aegyptiacae. Turnhout.

Lenoir, R. (ed., 2002). Pétrarque. L'Afrique. Grenoble.

Lind, L. (ed., 1942). The Vita Sancti Malchi of Reginald of Canterbury. Urbana, IL.

Lindsay, W. (ed., 1911). [Isidore of Seville]. Isidori Hispalensis episcopi Etymologiarum siue originum libri XX. Oxford.

Mann, J. (ed., 1987). Ysengrimus. Text with translation, commentary, and introduction. Leiden/ New York/Copenhagen/Berlin.

Mann, J. (ed., 2013). Ysengrimus. Edited and translated by J. Mann. Revised edition. London/ Cambridge, MA.

McGill, S. C. (ed., 2016). Juvencus' Four books of the gospels: Evangeliorum libri quattuor. London/New York.

Merzdorf, T. (ed., 1875). Troilus Alberti Stadensis [Albert of Stade]. Leipzig.

Migne, J.-P. (1852). Hrabanus Maurus. De uniuerso libri XXII, Patrologia Latina 111: 9-614.

Migne, J.-P. (1854). Historia Theophili metrica, Patrologia Latina 171: 1593-604. 
Migne, J.-P. (1855). Alan of Lille. Liber in distinctionibus dictionum theologicalium, Patrologia Latina 210: 685-1012.

Mora, F. (ed., 2003). Joseph d'Exeter [Joseph of Exeter]. L'lliade. Épopée du XXI ${ }^{\mathrm{e}}$ siècle sur la guerre de Troie. Turnhout.

Munari, F. (ed., 1988). Mathei Vindocinensis [Matthew of Vendôme]. Opera III: Ars uersificatoria. Rome.

Robertini, L./Giovini, M. (eds., 2004). Rosvita di Gandersheim [Hrotsvitha of Gandersheim]. Poemetti agiografici e storici. Alessandria.

Roncaglia, A. (ed., 1941). Giovanni Boccaccio. Teseida. Delle nozze d’Emilia. Bari.

Schmidt, P. (ed., 1974). Johannes de Hauvilla [John of Hauville]. Architrenius. Munich.

Stohlmann, J. (ed., 1968). Anonymi historia Troyana Daretis Frigii [Dares Phrygius]. Untersuchungen und kritische Ausgabe. Wuppertal.

Strecker, K. (ed., 1935). Ecbasis cuisdam captiui per tropologiam. Hanover.

Strecker, K. (1951). Waltharius, in: K. Strecker (ed.), Poetae Latini Aevi Carolini, vol. VI.I. Weimar: 24-83.

Thilo, G./Hagen, H. (eds., 1881-1884). Servius Grammaticus [Servius auctus]. Commentarius in Vergilii Aeneidos libros. Leipzig.

Thurn, N. (ed., 1995). Ugolino Verino, Carlias. Ein Epos des 15. Jahrhunderts erstmals herausgegeben. Munich.

Trillitzsch, W. (ed., 1963). Ecbasis cuisdam captiui per tropologiam. Die Flucht eines Gefangenen (tropologisch). Leipzig.

Voigt, E. (ed., 1884). Ysengrimus. Halle.

Waquet, H. (ed., 1942). Abbon [Abbo]. Le Siège de Paris par les Normands: poème du IXe siècle. Paris.

Wetherbee, W. (ed., 2015). Poetic works. Bernardus Silvestris. London/Cambridge, MA.

Wetherbee, W. (2017). The Metamorphosis Goliae Episcopi: a revised edition, translation, and notes, Journal of Medieval Latin 27: 41-67.

Wright, T. (ed., 1866). Johannis de Garlandia [John of Garland]. De triumphis ecclesiae libri octo. London.

\section{Secondary literature}

Bate, M. (2004). Tempestuous poetry: storms in Ovid's Metamorphoses, Heroides and Tristia, Mnemosyne 57: 295-310.

Boyer, R. et al. (eds., 1988). L'épopée. Turnhout.

Hainsworth, J. (1991). The idea of epic. Berkeley, CA.

Jacobsen, P. (1986). Epos. I. Mittellateinische Literatur, Lexikon des Mittelalters 3: 2077-80.

Kaufmann, H. (1988). Signals of epicity in Derek Walcott's Omeros. Diss. Freiburg.

Lamarque, H. (2002). Préface, in: R. Lenoir (ed.), Pétrarque. L'Afrique. Grenoble: 5-18.

Lapidge, M. (1979). Aldhelm's Latin poetry and Old English verse, CompLit 31: 209-31.

Mellmann, K. (2017). Zeit- und Ortsangaben im Deutschen Novellenschatz. Vorüberlegungen zur

Messung von Epizität, Zeitschrift für Literaturwissenschaft und Linguistik 47: 49-66.

Meyer, W. (1905). Gesammelte Abhandlungen zur mittellateinischen Rythmik. Berlin.

Orchard, A. (1994). The poetic art of Aldhelm. Cambridge.

Paquette, J.-M. (1988). Définition du genre, in: R. Boyer et al. (eds.), L'épopée. Turnhout: 13-35. 
Praet, S. (2013). The Trojan ass: Asinarius as mock epic, Viator 44: 157-73.

Praet, S. (forthcoming). Fairy tales and the Latin tradition: the case of the Donkey Prince. Detroit.

Roberts, M. (1989). The jeweled style: poetry and poetics in Late Antiquity. Ithaca.

Russell, J. S. (1988). The English dream vision. Anatomy of a form. Ohio.

Schaller, D. (1983). De Karolo rege et Leone papa, in: K. Langosch/K. Ruh (eds.), Die Deutsche Literatur des Mittelalters: Verfasserlexikon 4. Berlin/New York: 1044-5.

Schaller, D. (1989). Das mittelalterliche Epos im Gattungssystem, in: W. Erzgräber (ed.), Kontinuität und Transformation der Antike im Mittelalter. Sigmaringen: 355-79.

Schaller, D. (1993). La poesia epica, in: G. Cavallo (ed.), Il Medioevo Latino: la produzione del testo. Rome: 9-42.

Tyssens, M. (1988). L'épopée latine, in: R. Boyer et al. (eds.), L'épopée. Turnhout: 37-52.

Verbaal, W. (2004). Wolven op de Blandijn: Gentse kanttekeningen bij de Ysengrimus, Handelingen der Maatschappij voor Geschiedenis en Oudheidkunde te Gent 58: 83-104.

Verbaal, W. (2011). Homer im lateinischen Mittelalter, in: A. Rengakos/B. Zimmermann (eds.), Homer Handbuch: Leben-Werk-Wirkung. Stuttgart: 329-36.

Verbaal, W. (2016a). Loire Classics. Reviving classicism in some Loire poets, Interfaces 3: 10928.

Verbaal, W. (2016b). Properas extrorsum introrsus eundo. Epiek en anti-epiek in de Ysengrimus, Lampas 49: 378-91.

Ward, J. (1993). After Rome. Medieval epic, in: A. J. Boyle (ed.), Roman epic. London/New York: 261-93. 